\title{
The Role of cAMP in Beta Cell Stimulus-Secretion and Intercellular Coupling
}

\author{
Andraž Stožer ${ }^{1}$, Eva Paradiž Leitgeb ${ }^{1}$, Viljem Pohorec ${ }^{1}$, Jurij Dolenšek ${ }^{1,2}{ }^{\mathbb{D}}$, Lidija Križančić Bombek ${ }^{1}$, \\ Marko Gosak 1,2 (D) and Maša Skelin Klemen 1,*(D) \\ 1 Institute of Physiology, Faculty of Medicine, University of Maribor, SI-2000 Maribor, Slovenia; \\ andraz.stozer@um.si (A.S.); eva.paradiz1@um.si (E.P.L.); viljem.pohorec@um.si (V.P.); \\ jurij.dolensek@um.si (J.D.); lidija.bombek@um.si (L.K.B.); marko.gosak@um.si (M.G.) \\ 2 Faculty of Natural Sciences and Mathematics, University of Maribor, SI-2000 Maribor, Slovenia \\ * Correspondence: masa.skelin@um.si; Tel.:+386-2245-5873
}

Citation: Stožer, A.; Paradiž Leitgeb, E.; Pohorec, V.; Dolenšek, J.; Križančić Bombek, L.; Gosak, M.; Skelin

Klemen, M. The Role of cAMP in Beta Cell Stimulus-Secretion and Intercellular Coupling. Cells 2021, 10, 1658. https://doi.org/10.3390/

cells10071658

Academic Editor: Md Shahidul Islam

Received: 5 May 2021

Accepted: 28 June 2021

Published: 1 July 2021

Publisher's Note: MDPI stays neutral with regard to jurisdictional claims in published maps and institutional affiliations.

Copyright: (c) 2021 by the authors. Licensee MDPI, Basel, Switzerland. This article is an open access article distributed under the terms and conditions of the Creative Commons Attribution (CC BY) license (https:/ / creativecommons.org/licenses/by/ $4.0 /)$.

\begin{abstract}
Pancreatic beta cells secrete insulin in response to stimulation with glucose and other nutrients, and impaired insulin secretion plays a central role in development of diabetes mellitus. Pharmacological management of diabetes includes various antidiabetic drugs, including incretins. The incretin hormones, glucagon-like peptide- 1 and gastric inhibitory polypeptide, potentiate glucosestimulated insulin secretion by binding to $G$ protein-coupled receptors, resulting in stimulation of adenylate cyclase and production of the secondary messenger cAMP, which exerts its intracellular effects through activation of protein kinase A or the guanine nucleotide exchange protein $2 \mathrm{~A}$. The molecular mechanisms behind these two downstream signaling arms are still not fully elucidated and involve many steps in the stimulus-secretion coupling cascade, ranging from the proximal regulation of ion channel activity to the central $\mathrm{Ca}^{2+}$ signal and the most distal exocytosis. In addition to modifying intracellular coupling, the effect of cAMP on insulin secretion could also be at least partly explained by the impact on intercellular coupling. In this review, we systematically describe the possible roles of cAMP at these intra- and inter-cellular signaling nodes, keeping in mind the relevance for the whole organism and translation to humans.
\end{abstract}

Keywords: cAMP; beta cells; stimulus-secretion coupling; intercellular coupling; PKA; Epac2A

\section{Introduction}

Insulin secreted by pancreatic beta cells regulates storage and usage of nutrients, and its relative or absolute lack results in diabetes mellitus that affects more than 460 million people around the world, a number that is expected to increase to 700 million by 2045 [1]. If we consider also undiagnosed diabetes, the picture is even worse. The disease burden is immense and includes both public and personal costs [2], with total annual global health expenditures for diabetes estimated to more than 760 billion USD [1]. More than 95\% of all people with diabetes have type 2 diabetes mellitus (T2DM), which is characterized by obesity, insulin resistance, and insufficient insulin secretion [3]. Numerous antidiabetic drugs with different molecular mechanisms are available for T2DM treatment, among which sulfonylureas (SUs) are the most widely prescribed. They are very potent antidiabetic drugs, sufficient to activate the so-called triggering pathway, but bear a risk of hypoglycemia and weight gain [4]. The triggering pathway of insulin secretion in beta cells consists of several steps (Figure 1), starting with the influx of glucose through glucose transporters (GLUT), glucose metabolism increasing cytosolic adenosine-triphosphate (ATP) concentration, and the subsequent closure of ATP-dependent $\mathrm{K}^{+}\left(\mathrm{K}_{\text {ATP }}\right)$ channels. The decrease in $\mathrm{K}^{+}$efflux causes membrane depolarization, followed by the opening of voltage-dependent $\mathrm{Ca}^{2+}$ (VDCC) channels and the influx of $\mathrm{Ca}^{2+}$ ions. The resulting increase in the intracellular concentration of $\mathrm{Ca}^{2+}\left(\left[\mathrm{Ca}^{2+}\right]_{\mathrm{IC}}\right)$ triggers insulin secretion by activating the secretory machinery and fusion of insulin-containing vesicles with the plasma membrane [5-7]. SUs 
stimulate insulin secretion by closing $\mathrm{K}_{\mathrm{ATP}}$ channels by binding to their SU receptor 1 (SUR1) [8-11]. Besides the risk of hypoglycemia, chronic treatment with certain SUs could lead to the progressive failure of beta cells, since tolbutamide and glibenclamide were found to induce beta cell apoptosis in rat [12] and human islets [13].

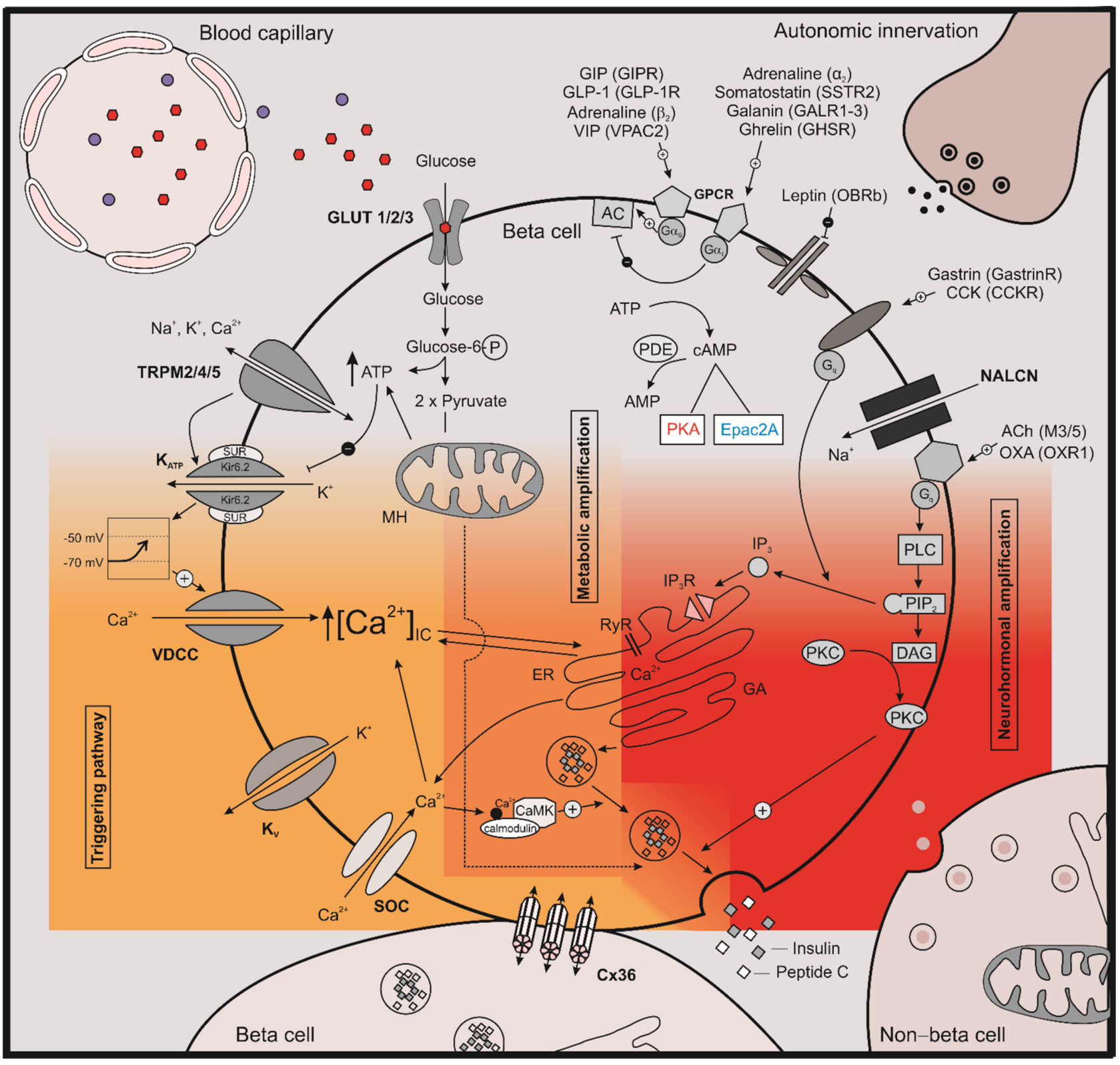

Figure 1. Stimulus-secretion coupling in beta cells. The three interconnected intracellular signaling pathways in pancreatic beta cells are shown; the $\mathrm{K}_{\mathrm{ATP}}$ dependent triggering pathways is indicated in dark yellow, the metabolic amplifying pathway in orange, and the neurohormonal amplifying pathway in red. Parts of a non-beta cell and a neighboring Cx36-connected beta cell are shown on the bottom, blood capillary and autonomic innervation are shown on top. GLP1-glucagon-like peptide 1; GIP-glucose-dependent insulinotropic peptide; GIPR—glucose-dependent insulinotropic peptide receptor; GLP-1R_-glucagon-like peptide 1 receptor; b2-beta-2 adrenergic receptor; a2-alpha-2 adrenergic receptor, VPAC2-vasoactive intestinal peptide receptor 2; GALR1-3—galanin receptor 1-3; SSTR2—somatostatin receptor 2; GHSR — growth hormone secretagogue receptor; OCRb-long form of the leptin receptor; M3-5-muscarinic acetylcholine receptor 3-5; OXA—orexin A; OXR1-Orexin-1 receptor; GPCR—G-protein-coupled receptor; cAMP—cyclic adenosine monophosphate; AMP—adenosine monophosphate, PDE—phosphodiesterase; PKA—protein kinase A; Epac2A—exchange protein directly activated by cAMP; TRPM — transient receptor potential melastatin; $\mathrm{K}_{\mathrm{ATP}}$ - ATP dependent potassium channel; Kir6.2—-major subunit of the ATP-depedent $\mathrm{K}^{+}$channel; SUR—sulfonylurea receptor; VDCC—voltage-dependent 
calcium channel; $\mathrm{K}_{\mathrm{v}}$-voltage-dependent potassium channels; SOC—Store-operated channel; $\mathrm{MH}-$ mitochindrion; AC—adenylyl cyclase, ER—endoplasmic reticulum; VIP—vasoactive intestinal polypeptide; ACh-acetylcholine, PLC— phospholipase C; $\mathrm{PIP}_{2}$ - phosphatidylinositol 4,5-bisphosphate; $\mathrm{IP}_{3}$-inositol trisphosphate; $\mathrm{IP}_{3} \mathrm{R}$-inositol trisphosphate receptor, DAG—diacylglycerol; PKC—-protein kinase C; GA—Golgi apparatus; $\mathrm{K}^{+}$— potassium ions; $\mathrm{Na}^{+}$—sodium ions; $\mathrm{Ca}^{2+}$-calcium ions; RyR-ryanodine receptors; Cx36-connexin-36; CAMK- $\mathrm{Ca}^{2+} /$ calmodulin-dependent protein kinase, glucose-6P-glucose- 6 phosphate; $\left[\mathrm{Ca}^{2+}\right]_{\mathrm{IC}}$-intracellular calcium concentration; $\mathrm{G}_{\mathrm{q}}-\mathrm{Gq}$ protein alpha subunit; Gas-Gs alpha subunit; Gai-Gi protein alpha subunit; NALCN—sodium leak channel; CCK—cholecystokinin; CCKR— cholecystokinin receptor.

Beside SUs, the incretin-related drugs are increasingly being used for stimulation of insulin secretion. The incretin hormones secreted from the gut augment insulin secretion observed after an oral glucose intake compared with that observed after identical elevation of plasma glucose with a controlled intravenous infusion of glucose [14-20]. Among incretins, glucose-dependent insulinotropic polypeptide (GIP) and glucagon-like peptide-1 (GLP-1) are the most investigated [21]. GIP and GLP-1 are released into the bloodstream from enteroendocrine $\mathrm{K}$ and $\mathrm{L}$ cells, respectively, following meal ingestion [22,23]. In pancreatic beta cells, GIP and GLP-1 bind to the specific guanine nucleotide-binding protein-coupled receptors (GPCR) GIPR and GLP-1R, respectively [24-26]. While, in healthy humans, oral administration of glucose triggers higher insulin secretion than a comparable glucose challenge intravenously due to the incretin effect, in T2DM, this phenomenon is partly lost, but the attenuated insulinotropic action is observed only for GIP. On the other hand, the actions of GLP-1 remain relatively preserved, although the levels of GLP-1 are significantly decreased [27-29]. Therefore, therapeutic approaches are mainly oriented at enhancing GLP-1 action through degradation-resistant GLP-1R agonists (incretin mimetics) or through inhibitors of the enzyme dipeptidyl-peptidase- 4 , which is responsible for a rapid degradation of incretin hormones. The effect of GLP-1 administration in humans was described over 20 years ago [30], leading to development of GLP-1 based therapies for T2DM [31], and improved drugs with GLP-1R agonist activity are currently being developed [32]. In mice, GLP-1 or GLP1-R agonists clearly improve glucose tolerance and increase glucose stimulated insulin secretion (GSIS), their effects ranging from normal mice [32] to the alloxan-induced diabetic model [33]. Accordingly, the oral glucose tolerance test (OGTT), known to elicit release of incretins, results in larger increase of blood glucose levels in GLP1-R knock-out (KO) mice compared with wild-type mice, corroborating the importance of GLP-1R signaling for normal glucose tolerance [34]. Noteworthy, GLP-1R KO mice are glucose-intolerant also in intraperitoneal glucose tolerance tests (ipGTTs), in which the level of incretins is not increased. Therefore, it seems that even the basal level of GLP-1 or some constitutive activity of the GLP-1R signaling pathway is important for normal glucose tolerance. Furthermore, inhibition of GLP-1R with an antagonist Exendine-9 reduces the insulin response to oral glucose by $30-40 \%$ [35] but with 1.5- to 2 -fold variability among nondiabetic subjects [36], which points to differences in the $\beta$-cell sensitivity to GLP-1. The GLP-1R sensitivity can be calculated from the insulin secretion rate using a progressive increase in plasma GLP-1 via infusion during a hyperglycemic clamp. In nondiabetic human subjects, the obese individuals who are more insulin resistant showed increased slope of insulin secretion rate in response to stepwise elevation of GLP-1 compared to lean individuals [37]. Sensitivity of insulin secretion to GLP-1 is clinically important because of the reduced incretin effect in T2DM patients [38], a finding recently proposed to extend to obese subjects $[37,39]$. Since incretins have almost no effect on insulin secretion in low glucose $[40,41]$, this makes them a much safer option in terms of risk of hypoglycemia compared with SUs. In addition to the established effects on beta cell insulin secretion, GLP-1 also seems to induce a paracrine beta cell response, which leads to alpha cell proglucagon processing that results in GLP-1 production. This process is not yet fully understood; however, it may be metabolically relevant [42]. 
In pancreatic beta cells, GLP-1 and GIP exhibit their effect through the so-called neurohormonal amplifying pathway (Figure 1). Binding to GPCR results in interaction with the G $\alpha$ s subunit, with subsequent activation of adenylyl cyclase and consecutive production of $3^{\prime}, 5^{\prime}$-cyclic adenosine monophosphate (cAMP) from ATP. In beta cells, cAMP is one of the most important cellular signaling molecules that amplifies insulin secretion elicited by the triggering signal. On the other hand, degradation of cAMP to $5^{\prime}$-AMP is regulated by phosphodiesterases (PDEs), and cAMP lowering agents thus inhibit insulin secretion (Figure 1). It was found that CAMP signaling in not only triggered by GPCR agonists but also under glucose stimulation promoting cAMP elevation with pronounced oscillations. This $\mathrm{Ca}^{2+}$-dependent mechanism activates certain adenylyl cyclases (AC) and is important mainly at substimulatory glucose concentration, while, under increased glucose concentration, a metabolic amplification of cAMP also becomes important [43]. The actions of cAMP are further mediated via protein kinase A (PKA) and the guanine nucleotide exchange factor Epac2A. It was also shown recently that PKA isoform with Ri $\alpha$ (PKA-Ri $\alpha$ ) could act independently of the cAMP signaling mechanism [44]. On the other hand, Epac2A is also directly activated by various SUs, except for gliclazide, and activation of Epac2A signaling seems to be required for SU-induced insulin secretion $[33,45,46]$. Furthermore, binding properties of various SUs to Epac2A were quantified, and it was found that cAMP and SUs cooperatively activate Epac2A [47,48]. This molecular mechanism provides a possible explanation for additive effects of combination therapies of incretin-related drugs and SUs, although many important questions still need to be answered in this regard.

Since the incretin effect in pancreatic beta cells is mediated via the neurohormonal amplifying pathway through PKA and Epac2A, the specific role of PKA in glucose homeostasis was assessed in vivo by disinhibiting PKA activity in a genetic mouse model [49]. A conditional homozygous ablation of the PKA regulatory subunit (Prkar1a KO) resulted in increased glucose tolerance with a concomitantly enhanced GSIS after ipGTT. The enhancing role of PKA was confirmed also in humans in the same study [49]. When crossing Prkar1a KO mice with Epac2A KO mice, the resultant Prkar1/Epac2A KO mice exhibited a reduction in GSIS compared with Prkar1a KOs [50]. This implicates that Epac2A expression is permissive and necessary for the maximum effect of GLP-1R stimulation on GSIS.

Regarding the role of Epac2A, several studies demonstrated that Epac2A ablation failed to exert any influence either on glucose tolerance or on GSIS after ipGTT in mice [46,50,51]. Interestingly, Epac2A KOs exhibit early morphological (e.g., increased fat deposits) and biochemical (e.g., increased leptin and decreased adiponectin serum levels) signs of obesity, but these changes are connected with suppressed hypothalamic leptin signaling [51]. On the other hand, when beta cell insulin secretion was potentiated pharmacologically by GLP-1R activators, the neurohormonal amplifying pathway was activated, and Epac2A KO mice revealed an impaired glucose tolerance and GSIS during ipGTT [50]. This suggests that Epac2A plays a crucial role in mediating the effects of incretins on GSIS rather than contributing to GSIS without additional stimulation by incretins. Surprisingly, the same study reported that, during OGTT, glucose tolerance was not perturbed in Epac2A KO mice [50]. It is possible that Epac2A plays a role in increasing GSIS at pharmacological levels of GLP-1-R stimulation but not at more physiological concentrations of GLP-1 reached during an OGTT. Furthermore, Epac2A seems to be important also during the development of insulin resistance and in combination therapies for T2DM treatment involving incretins and SUs. In sum, the role of GLP-1R signaling in maintaining normal glucose tolerance in general and the differential roles of Epac2A and PKA arms of this neurohormonal amplifying pathway in specific await further clarification.

Beta cells in the pancreatic islets display coordinated insulin secretion. This is a result of different means of intercellular communication, which ensures that heterogeneous beta cell populations work in synchrony [52-54]. Gap junctions composed of connexin36 (Cx36) are the key synchronizing agents that coordinate electrical activity across the islet in the form of intercellular waves [55-58]. Recent research suggests that impaired gap junction coupling is associated with disruptions to glucose homeostasis, altered islet function, and 
impaired plasma insulin oscillations, similar to that observed in models of diabetes [59-63]. In this vein, cell-to-cell communication was recognized as one of the underlying factors which contributes to the pathogenesis of diabetes [64,65]. Furthermore, intercellular coupling in islets as well as in other systems was also reported to be modulated by cAMP signaling, but the findings about the effects of PKA-dependent and PKA-independent mechanism involving Epac2A are rather diverse [66-74]. This underlines the necessity for further studies on how the neurohormonal signaling pathways influence gap-junctional communication and the collective rhythmic activity in islets, as the effect of cAMP on insulin secretion could also be at least partly explained by the impact on intercellular coupling.

Taken together, PKA and Epac2A may play an important role in (i) normal glucose homeostasis, (ii) incretin potentiation of GSIS, (iii) potentiation of GSIS in obesity, and (iv) potentiation of GSIS in combination therapy involving SUs and incretins. The molecular mechanisms behind this are still not fully elucidated and involve many steps in stimulussecretion coupling (SSC), ranging from the regulation of ion channel activity and the triggering $\mathrm{Ca}^{2+}$ signal to the most distant step in SSC, exocytosis. Finally, the effect of cAMP on insulin secretion could at least partly be explained also by the impact on intercellular coupling. In the subsequent chapters of this review, we focus on these intraand inter-cellular mechanisms in more detail.

\section{The Role of cAMP on Stimulus Secretion Coupling}

\subsection{The Effect of cAMP on Ion Channels}

$\mathrm{Ni}$ et al. found that oscillations in PKA activity directly mirror the oscillations in cAMP levels [75]. The cAMP-mediated potentiation of insulin secretion is further regulated by (i) activators of AC and (ii) inhibitors of PDEs, which degrade cAMP, and (iii) is stimulated by high $\left[\mathrm{Ca}^{2+}\right]_{\text {IC }}[76]$.

Since AC is a transmembrane protein, the highest cAMP concentration can be expected to be at the submembrane compartment, which is of great relevance for the regulation of ion channels (Figure 2A) and for the process of exocytosis [43]. Moreover, research shows that submembrane cAMP levels vary locally to a great extent. This is attributed to A-kinase anchoring proteins (AKAPs) which scaffold AC of different isoforms, PKA, GPCR, $\mathrm{PDE}$, and other pertaining signaling components in cAMP production into very confined compartments to generate local ATP pools [77]. This clustering of $\mathrm{Ca}^{2+}$-sensitive AC into nanodomains is then responsible for local increases in cAMP levels, which are exactly in-phase with $\mathrm{Ca}^{2+}$ oscillations, whereas localized PDE is responsible for the out-of-phase decreases in local cAMP [78]. 

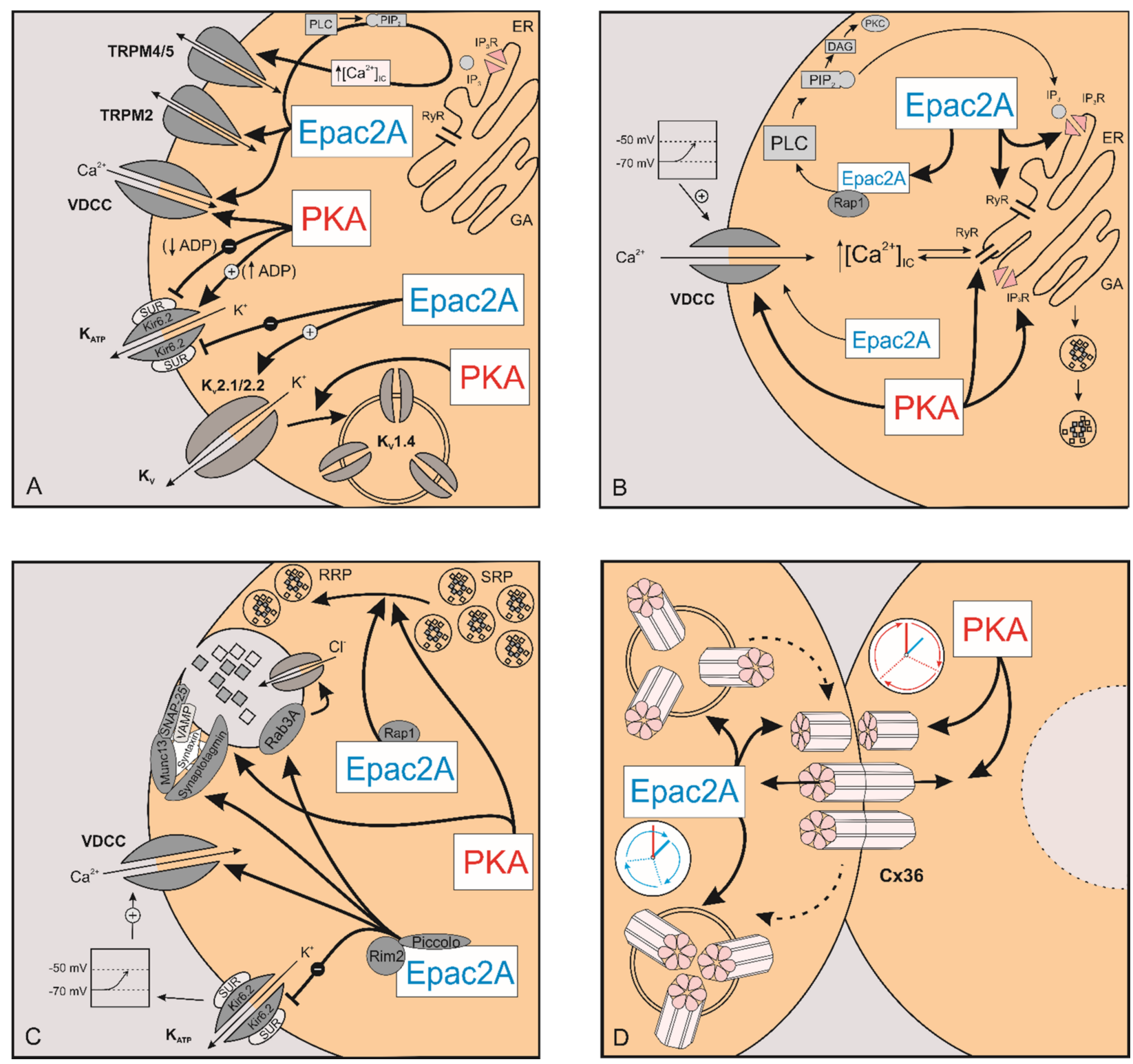

Figure 2. The role of PKA and Epac2A in stimulus-secretion and intercellular coupling. The effect of PKA and Epac2A on ion channels (A), $\left[\mathrm{Ca}^{2+}\right]_{\mathrm{IC}}(\mathbf{B})$, exocytosis (C), and intercellular coupling (D). PKA—protein kinase A; Epac2A—exchange protein directly activated by CAMP; TRPM2—-transient receptor potential melastatin 2; TRPM4/5-transient receptor

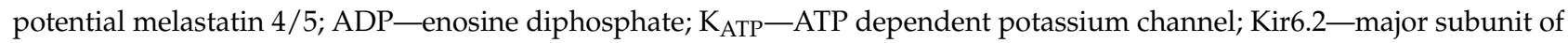
the ATP-depedent $\mathrm{K}^{+}$channel; SUR—sulfonylurea receptor; VDCC—voltage-dependent calcium channel; $\mathrm{K}_{\mathrm{v}}$-voltagedependent potassium channels; ER—endoplasmic reticulum; PLC—phospholipase C; $\mathrm{PIP}_{2}$ - phosphatidylinositol 4,5bisphosphate; $\mathrm{IP}_{3}$-inositol trisphosphate; $\mathrm{IP}_{3} \mathrm{R}$-inositol trisphosphate receptor, DAG—diacylglycerol; PKC—protein kinase $\mathrm{C}$; GA-Golgi apparatus; $\mathrm{K}^{+}$- potassium ions; $\mathrm{Na}^{+}$- sodium ions; $\mathrm{Ca}^{2+}$ - calcium ions; $\mathrm{Cl}^{-}$- chloride ions; $\mathrm{RyR}$ ryanodine receptor; $\mathrm{Cx36}$ - connexin-36; $\left[\mathrm{Ca}^{2+}\right]_{\mathrm{IC}}$-intracellular calcium concentration; Rim2-Rab GTPase interacting molecule; Rpa1-Ras-related protein 1; Munc13-mammalian uncoordinated-13; VAMP_vesicle-associated membrane protein; Rab3A—Ras-related protein Rab-3A; SNAP-25—synaptosomal-associated protein 25; RRP—readily-releasable pool; SRP—slowly releasable pool.

\subsubsection{KATP Channels}

$\mathrm{K}_{\text {ATP }}$ channels belong to a family of inward-rectifying $\mathrm{K}^{+}$channels [79]. They are composed of four potassium-selective pore-forming Kir6.2 subunits which have binding sites for ATP and four regulatory SUR1 subunits with binding sites for MgADP, enabling 
them to be controlled by changes in intracellular ATP concentration ([ATP $\left.]_{\mathrm{IC}}\right)$ and the ratio of intracellular ATP to adenosin diphosphate $\left(\left[\mathrm{ADP}_{\mathrm{IC}}\right]\right)[\mathrm{ATP}]_{\mathrm{IC}} /[\mathrm{ADP}]_{\mathrm{IC}}[80,81]$.

Light et al. demonstrated that PKA regulates $\mathrm{K}_{\mathrm{ATP}}$ channels in an ADP-dependent manner [82]. When glucose concentration is high, the cytoplasmic ADP levels are relatively low (ATP production is high), and PKA inhibits $\mathrm{K}_{\text {ATP }}$ channels, while, at elevated ADP levels (low glucose), it increases their activity. As proposed by some authors, this regulation is governed by a molecular mechanism which includes ADP-sensitive binding of PKA to the Kir6.2 subunit at serine residue S372 or to the SUR1 subunits of $\mathrm{K}_{\text {ATP }}$ channels at serine residues $\mathrm{S} 1571$ (human only) and S1448 [82,83].

Inhibition of $\mathrm{K}_{\mathrm{ATP}}$ channels can also be mediated by Epac2A [84]. Some 20 years ago, in vitro studies demonstrated that Epac2A interacts with the nucleotide-binding fold-1 (NBF-1) at the SUR1 subunit of the $\mathrm{K}_{\text {ATP }}$ channel [85-87]. Since SUR1 also binds with Kir6.2 subunit to form functional inwardly rectifying $\mathrm{K}_{\mathrm{ATP}}$ channels [79], this finding suggested that Epac2A might serve as an accessory subunit of the $\mathrm{K}_{\mathrm{ATP}}$ channel. The interaction of Epac2A and SUR1 may explain why cAMP elevating agents (e.g., forskolin, glucagon) inhibit $\mathrm{K}_{\mathrm{ATP}}$ channel functioning. Indeed, the study by Kang et al. confirmed that, in human $\beta$ cells and rat insulin-secreting INS-1 cell line, cAMP analogues selective for the Epac2A pathway inhibit the functioning of $\mathrm{K}_{\mathrm{ATP}}$ channels [84]. This regulation by Epac2A is of great interest since it was reported that SUs can directly activate Epac $2 \mathrm{~A}$ and that activation of Epac2A signaling is required for SU-induced insulin secretion $[33,45,46]$.

\subsection{2. $\mathrm{K}_{\mathrm{V}}$ Channels}

In human beta cells, the voltage-dependent $\mathrm{K}^{+}$current is mediated by delayed rectifying $\mathrm{K}^{+}\left(\mathrm{K}_{\mathrm{V}}\right)$ channels and big $\mathrm{K}^{+}$conductance (BK) channels [88], which are involved in the repolarization phase of action potentials [89]. Among the $K_{v}$ channels, $K_{v} 2.1$ channels are an important component of the delayed rectifying current identified in mammalian beta cells $[90,91]$. However, there are substantial differences in ion channel subtypes among species that shape the action potentials [5]. In mice, the most widespread channels are the $\mathrm{K}_{\mathrm{v}} 2.1$ [88], whereas, in men, single cell transcriptome profiling revealed that the expression of KCNB2 gene, which encodes $\mathrm{K}_{\mathrm{v}} 2.2$, is nearly 10-fold higher than the expression of KCNB1 encoding $K_{v} 2.1$, suggesting a dominant role of $K_{v} 2.2$. in human beta cells [92]. Together, $\mathrm{K}_{\mathrm{v}} 2.1$ and $\mathrm{K}_{\mathrm{v}} 2.2$ channels account for $65 \%-80 \%$ of potassium currents in human beta cells, and their inhibition with various inhibitors increases beta cell activity [89,93].

Recent studies reported that $\mathrm{K}_{\mathrm{v}}$ channels are inhibited by cAMP, which results in prolongation of action potential duration, subsequently elevating intracellular $\mathrm{Ca}^{2+}$ induced by activation of cAMP signaling [94], and magnesium-ATP (MgATP) plays a pivotal role in maintaining the activity of $\mathrm{K}_{\mathrm{v}} 2.1$ channels [95]. An electrophysiological study of isolated rat beta cells reported that $\mathrm{K}^{+}$currents through $\mathrm{Kv}$ channels are regulated by cAMP/PKA and not by the protein kinase C (PKC) pathway [96]. Additionally, the effect of a xanthine derivative, which increases cellular cyclic nucleotides and activates $\mathrm{K}^{+}$channels in high glucose (KMUP-1), was reversed by the PKA inhibitor H-89, suggesting that KMUP-1 might be a promising pharmacological substance for treating insulin resistance [96].

Another mechanism regulating $\mathrm{K}_{\mathrm{v}}$ channels was described to work through incretin stimulation of PKA. Kim et al. reported that the incretin hormone GIP suppressed ionic current through $\mathrm{K}_{\mathrm{v}} 1.4$ channels by activating PKA, which phosphorylates the C-terminal domain of $\mathrm{K}_{\mathrm{v}} 1.4$ channel and mediates rapid phosphorylation-dependent endocytosis of $\mathrm{K}_{\mathrm{v}}$ 1.4. This mechanism highlights an important novel role for GIP in regulating surface expression of $K_{v} 1.4$ channels and modulation of potassium currents [97]. Since $K_{\mathrm{v}}$ channels are responsible for the repolarization phase of action potentials [89], endocytosis of Kv1.4 channels would result in slower decrease of membrane potential, thus further prolonging insulin secretion. 
Many other delayed rectifying $\mathrm{K}_{\mathrm{v}}$ channels are present in beta cells and may have roles other than mediating the $\mathrm{K}^{+}$efflux. Specifically, $\mathrm{K}_{\mathrm{v}} 2.1$ channels were reported to directly facilitate insulin secretion [98] through interaction with Syntaxin-1A and SNAP-25 in the SNARE complex of the exocytotic machinery $[99,100]$.

\subsubsection{TRP Channels}

Auxilliary depolarizing or "leak" currents are mainly carried by influx of $\mathrm{Na}^{+}$ions through transient receptor potential (TRP) channels, of which beta cells express many subtypes. Some of them are also permeable to $\mathrm{Ca}^{2+}$ (e.g., TRPA1, TRPC1, TRPC4, TRPM2, TRPM3, TRPM5, TRPV1, TRPV2, and TRPV4). Each TRP channel consist of four subunits which may not be of the same type, giving rise to a variety of ion channels that are regulated through various mechanisms [101]. For many TRP channels, their main roles are known, but not for all of them, and even less is known about the mechanisms that regulate their gating, selectivity, and interactions. Only those with known regulatory mechanism in beta cells are briefly presented here.

TRPM2 channels are expressed on cell membranes of rodent and human beta cells as well as in many cell lines and are involved in insulin secretion in response to glucose stimulation [102,103]. Their most potent activator is cyclic ADP-ribose (cADPR) [104], but the channel opening also requires binding of $\mathrm{Ca}^{2+}$ to the transmembrane domains $[105,106]$. Other activators include nitric oxide, $\mathrm{H}_{2} \mathrm{O}_{2}$, free radicals, and $\beta-\mathrm{NAD}^{+}$. TRPM2 was shown to activate with nanomolar concentrations of GLP-1 through the cAMP-Epac2A pathway $[103,107,108]$, but the involvment of cADPR and a glucose stimulus are needed [109]. Contrarily, inhibition of cAMP signaling was achieved by low concentration of adrenaline, which activates $\alpha 2 \mathrm{~A}$ adrenoceptors [110], by nanomolar ghrelin concentrations [111], and by low $\mathrm{pH}$ [112]. Yoshida et al. showed that activation of nonselective cation currents through TRPM2 channels by glucose and GLP-1 facilitates membrane depolarization and elevates cAMP concentration, which activates the Epac2A-mediated pathway. In addition, nonselective cation currents were attenuated in TRPM2-deficient mice and were not activated in the presence of PKA activators, supporting the stimulatory role of Epac2A and not PKA in the regulation of TRPM2 [108].

To summarize, the most prominent effect of cAMP/Epac2A/PKA pathway on plasma membrane channels and the ionic fluxes which regulate insulin secretion is the inhibition of $\mathrm{K}_{\mathrm{ATP}}$ channels by Epac2A, the inhibition of $\mathrm{K}_{\mathrm{V}}$ channels by cAMP, and the $\mathrm{K}_{\mathrm{V}} 1.4$ endocytosis.

\subsection{The Effect of $c A M P$ on $\left[\mathrm{Ca}^{2+}\right]_{I C}$}

The effect of GLP-1 on $\left[\mathrm{Ca}^{2+}\right]_{\mathrm{IC}}$ (Figure $\left.2 \mathrm{~B}\right)$ was recorded in rodent as well as human beta cells [113-116]. In low glucose, which does not increase $\left[\mathrm{Ca}^{2+}\right]_{\text {IC }}$ per se, cAMP has almost no effect on insulin secretion $[40,41]$, and cAMP-elevating agents are unable to raise $\left[\mathrm{Ca}^{2+}\right]_{\mathrm{IC}}$ in the absence of stimulatory glucose concentration $[109,117,118]$. This indicates that the amplifying effect of GLP-1 requires interaction with the triggering $\left[\mathrm{Ca}^{2+}\right]_{\mathrm{IC}}$ signal. GLP-1 increases voltage-dependent $\mathrm{Ca}^{2+}$ currents by increasing the activity of L-type VDCCs, and the inhibition of said channels inhibits $\left[\mathrm{Ca}^{2+}\right]_{\mathrm{IC}}$ rise in response to GLP-1 or forskolin [119-122]. Increased $\mathrm{Ca}^{2+}$ influx through L-type VDCC is due to (i) a leftward shift in voltage dependent activation and (ii) rightward shift in voltage dependent steadystate inactivation. A leftward shift in voltage dependent activation means that the maximal current through the channels is recorded at a lower membrane potential when GLP-1 is added. This is likely mediated by a PKA-induced phosphorylation of the channels. Due to a rightward shift in steady-state inactivation curve, fewer channels are inactivated at a given membrane potential and are therefore ready to be activated once again at a higher membrane potential $[123,124]$. 
Of the two L-VDCC subtypes expressed in beta cells, both can mediate the GLP-1induced potentiation of glucose-induced insulin secretion, however, $\mathrm{Ca}_{\mathrm{v}} 1.3$ seems to be preferentially coupled to GLP-1 receptor activation. This signaling pathway depends on intact intracellular stores, PKA and PKC activation [125]. While both Epac2A and PKA are important in regulating the activity of Cav1.2, Cav1.3 activation is mainly a PKA-dependent process, in which Epac2A has a secondary role [125,126].

The effect of cAMP on beta cell $\mathrm{Ca}^{2+}$ signaling is not restricted to the voltage-dependent $\mathrm{Ca}^{2+}$ influx but also involves PKA-dependent and PKA-independent $\mathrm{Ca}^{2+}$ mobilization from internal stores (Figure 2B) [122,127-129]. Following beta cell depolarization and activation of VDCCs, $\mathrm{Ca}^{2+}$ entering cytoplasm triggers additional release of $\mathrm{Ca}^{2+}$ from intracellular compartments [130]. The role of this process, known as $\mathrm{Ca}^{2+}$-induced $\mathrm{Ca}^{2+}$ release (CICR), in pancreatic beta cells is still incompletely understood, especially in terms of GSIS. Since thapsigargin failed to reduce insulin secretion, it was previously believed that CICR was of minor physiological importance in GSIS [131]. With utilization of $\mathrm{Ca}^{2+}$ indicators with enhanced sensitivity and high-resolution $\mathrm{Ca}^{2+}$ imaging, the latest research suggests that, even under glucose stimulation, intracellular $\mathrm{Ca}^{2+}$ stores play a crucial role in shaping beta cell $\mathrm{Ca}^{2+}$ responses [132]. Contrary to that, it is agreed that exendin-4, a high affinity GLP-1 agonist, facilitates CICR and that this mechanism importantly contributes to beta cell $\mathrm{Ca}^{2+}$ response [133-135].

To examine how cAMP elevating agents affect CICR in beta cells, a UV flash photolysis was used to rapidly uncage $\mathrm{Ca}^{2+}$ from NP-EGTA, a photolabile $\mathrm{Ca}^{2+}$ chelator. The uncaging of $\mathrm{Ca}^{2+}$ generated an increase in $\left[\mathrm{Ca}^{2+}\right]$ but did not induce CICR. The addition of exendin4 failed to induce $\left[\mathrm{Ca}^{2+}\right]_{\mathrm{IC}}$ increase in beta cells before uncaging of $\mathrm{Ca}^{2+}$ by $\mathrm{UV}$ flash photolysis, indicating the effect of exendin- 4 in this experiment was not mediated through membrane depolarization and subsequent opening of VDCC [133] but by sensitizing the intracellular $\mathrm{Ca}^{2+}$ release mechanism to the stimulatory effect of an increase in $\left[\mathrm{Ca}^{2+}\right]_{\mathrm{IC}}$, thereby allowing CICR to be triggered by uncaging of $\mathrm{Ca}^{2+}$ [129].

Several conflicting results were published regarding the role of PKA and Epac2A in modulation of beta cell internal $\mathrm{Ca}^{2+}$ stores, and molecular mechanisms remain obscure. Facilitation of CICR after exendin-4 stimulation was diminished but not abrogated in Epac2A KO islets, and PKA inhibition failed to (completely) prevent incretin-induced CICR in control islets $[109,133,136,137]$. While some studies show both PKA and Epac2A selective agonists can induce a rapid and sustained $\mathrm{Ca}^{2+}$ rise [109] or trigger CICR [129], other only recorded this response after PKA activation but not after application of Epac2A activators [138]. Taken together, it seems that both PKA-dependent and PKA-independent mechanisms contribute to cAMP-mediated release of intracellular $\mathrm{Ca}^{2+}$ stores. It is also worth pointing out that, while $\mathrm{Ca}^{2+}$ response remained unaffected, the inhibition of PKA nearly abolished the potentiating effect of Epac2A on glucose-induced insulin secretion, indicating that PKA has a permissive role operative further downstream in the stimulussecretion coupling cascade [122]. Since at least in vitro half maximal activations of PKA and Epac2A occur at different cAMP concentrations, the amount of cAMP synthesized in response to selected stimulating protocols could also contribute to variability of results obtained in different studies [134].

Most studies recognize the endoplasmic reticulum as the principal intracellular $\mathrm{Ca}^{2+}$ source. Depletion of the ER by thapsigargin, a potent inhibitor of sarco/endoplasmic reticulum $\mathrm{Ca}^{2+}$-ATPases (SERCA), typically deems beta cells unresponsive to GLP-1 as well as PKA and Epac2A-selective agonists [121,133,139]. However, mobilizing $\mathrm{Ca}^{2+}$ from ER stores is not the only feasible way to increase $\left[\mathrm{Ca}^{2+}\right]_{\mathrm{IC}}$. There is a report indicating that Epac2A activators might signal through nicotinic acid adenine dinucleotide phosphate (NAADP) receptors, known also as two-pore $\mathrm{Ca}^{2+}$ channels, to mobilize $\mathrm{Ca}^{2+}$ from non-ER compartments. These acidic stores are presumed to be responsible for the fast, transient phase of $\mathrm{Ca}^{2+}$ response [109]. However, other studies found these non-ER stores to be less likely to play a role in GLP-1 induced CICR [133]. 
Whether CICR is mediated via inositol trisphosphate receptors (IP3R) or ryanodine receptors (RYR) is still debatable. In beta cells, functional receptors of both types are present, with IP3R type 3 and RYR type 2 being the most abundantly expressed [121,140]. Some argue that PKA-mediated CICR via IP3 is the major mechanism by which cAMP amplifies insulin release [138]. The effect of Epac2A was also found to be associated with IP3R, secondary to Epac2A/Rap1-mediated activation of phospholipase C- $\varepsilon$ (Figure 2B) [133,141]. Others, however, reported that the $\mathrm{Ca}^{2+}$ rise in response to Epac2A-selective agonists was not accompanied by a detectable increase in IP3 and that pretreatment of cells with ryanodine or ruthenium red, antagonists of RYR, effectively blocked the $\mathrm{Ca}^{2+}$ response to incretins $[116,121,137]$. Additionally, the IP3R inhibitor xestospongin C did not affect the GLP-1 induced $\mathrm{Ca}^{2+}$ responses $[84,109,142]$. While opinions differ regarding the type of receptor, IP3 or RYR, it is generally accepted that the mobilization of intracellular stores induced by GLP-1 is cAMP-dependent [143] and acts via receptor sensitization [138]. Recent research shows that both types of receptors are important, at least in glucose-induced $\mathrm{Ca}^{2+}$ signaling [132].

cAMP also affects $\left[\mathrm{Ca}^{2+}\right]_{\mathrm{IC}}$ oscillations and other types of cellular responses, but a detailed characterization of changes in $\left[\mathrm{Ca}^{2+}\right]_{\mathrm{IC}}$ dynamics during metabolic amplification by cAMP is lacking in published literature. The qualitative and the quantitate diversity of results arise from the variety of methods and protocols used to investigate $\mathrm{Ca}^{2+}$ responses in pancreatic beta cells.

While both slow and fast $\left[\mathrm{Ca}^{2+}\right]_{\mathrm{IC}}$ oscillations rely on periodic entry of $\mathrm{Ca}^{2+}$, the fast pattern also seems to depend on mobilization of intracellular $\mathrm{Ca}^{2+}$ stores, and agents that increase cAMP promote the appearance of regular fast $\left[\mathrm{Ca}^{2+}\right]_{\mathrm{c}}$ oscillations $[132,144]$.

Older studies, where GLP-1 was applied in pulses ranging from $30 \mathrm{~s}$ [121] to a few minutes, typically report a rapid $\left[\mathrm{Ca}^{2+}\right]_{\text {IC }}$ peak, occasionally followed by a smaller, sustained $\left[\mathrm{Ca}^{2+}\right]_{\mathrm{IC}}$ elevation $[114,121]$. Holz et al. described two main temporal components of the GLP-1-induced $\left[\mathrm{Ca}^{2+}\right]_{\mathrm{IC}}$ dynamics and proposed a mechanism behind them. The first one is transient on the timescale of seconds and is believed to be due to CICR activated by a $\mathrm{Ca}^{2+}$ influx trough L-type VDCCs. The second, more sustained $\mathrm{Ca}^{2+}$ rise measured in minutes reflects an increased flux of $\mathrm{Ca}^{2+}$ ions through plasma membrane through L-type VDCCs as well as through nonselective cation channels. These fast $\mathrm{Ca}^{2+}$ transients were recorded in beta cells voltage-clamped at $50 \mathrm{mV}$, a membrane potential above the resting potential, to allow GLP-1 to promote the opening of VDCCs, and the rise in $\mathrm{Ca}^{2+}$ was not associated with a change in membrane current. However, the fast transients were blocked by nimodipine, exposure to a $\mathrm{Ca}^{2+}$-free medium, hypoglycemic glucose concentrations, thapsigargin, and ryanodine, all supporting the model where GLP-1 facilitates $\mathrm{Ca}^{2+}$ influx and RYR-mediated CICR to amplify insulin granule exocytosis [121]. Contrary to this, Kim et al. showed that only the late/sustained phase of $\mathrm{Ca}^{2+}$ signal is sensitive to thapsigargin and ryanodine, while the initial, transient part is thapsigargin-resistant and is believed to represent $\mathrm{Ca}^{2+}$ release from acidic stores [109].

When $\left[\mathrm{Ca}^{2+}\right]_{\mathrm{IC}}$ oscillations are recorded in response to glucose stimulation, addition of GLP-1 or cAMP agonists typically increases their frequency [115,145-147]. A more substantial rise in $[\mathrm{CAMP}]_{\mathrm{IC}}$ achieved by simultaneous activation of $\mathrm{AC}$ and inhibition of PDEs (IBMX) leads to a sustained, non-oscillatory increase in $\left[\mathrm{Ca}^{2+}\right]_{\mathrm{IC}}$, which is sometimes preceded by an escalation in oscillatory frequency [115]. This could indicate that both cAMP concentration and dynamics are relevant for the oscillatory character of $\mathrm{Ca}^{2+}$ responses. cAMP elevations in beta cell were also found to be oscillatory in response to both glucose and neurohormonal amplifiers, i.e., GLP-1. [78,148]. GLP-1 induced cAMP oscillations are synchronized with $\mathrm{Ca}^{2+}$ responses and are mirrored by changes in PKA and Epac2A activity [43,149]. Moreover, they are coupled with pulsatile insulin secretion [150]. While many aspects of this cAMP dynamic remain unclear, it seems that the brief elevations in cAMP help contain the effects of cAMP in specific, spatially limited cellular subdomains, affecting only some of the ion channels or the exocytotic machinery adjacent to these domains [43]. Additionally, various cellular subdomains could have different oscillatory 
patterns and concentrations of cAMP, and this especially discreet camp pool could affect whole cell $\mathrm{Ca}^{2+}$ oscillations and potentially insulin secretion [149]. In some older studies, the addition of GLP-1 during glucose stimulation of mouse islets caused either additional $\left[\mathrm{Ca}^{2+}\right]_{\text {IC }}$ elevation with attenuation or abolition of $\mathrm{Ca}^{2+}$ oscillations [136] or lengthening of the oscillations or a sustained peak [151]. These results as well as the ones above only describing transient and/or sustained elevation could be explained by technical limitations in measuring $\left[\mathrm{Ca}^{2+}\right]_{\mathrm{IC}}$. The older studies of Bode et al. and Flamez et al. used Fura-2 and Fure-PE3/AM, respectively, capturing emitted fluorescence by a CCD camera. Contemporary $\mathrm{Ca}^{2+}$ indicators that are compatible with confocal microscopy and have an improved sensitivity to rapid changes in $\mathrm{Ca}^{2+}$ dynamics offer enhanced insight into beta cell dynamics that was previously inaccessible [152].

To conclude, cAMP promotes $\mathrm{Ca}^{2+}$ influx through voltage dependent $\mathrm{Ca}^{2+}$ channels as well as its mobilization from intracellular stores. While Epac2A and PKA seem to be relevant for both mechanisms, precise molecular mechanisms remain uncertain. It is worth emphasizing that, while the changes in $\left[\mathrm{Ca}^{2+}\right]_{\mathrm{IC}}$ are minor, the amount of insulin secreted in response to cAMP elevation is much greater, indicating that the rise in $\left[\mathrm{Ca}^{2+}\right]_{\mathrm{IC}}$ is just one and probably not the most quantitatively important cAMP-sensitive step in reference [115].

\subsection{The Effect of cAMP on Exocytosis}

Distally to the triggering increase in $\left[\mathrm{Ca}^{2+}\right]_{\mathrm{IC}}$ in the SSC cascade, cAMP also directly affects exocytosis (Figure 2C) [127,153]. Total internal reflection fluorescencemicroscopy revealed that cAMP in the presence of glucose but not by itself enhances the frequency of fusion events of insulin granules during both phases of insulin secretion [45]. This action seems to consist of both a PKA-dependent and a PKA-independent mechanism. The latter, involving activation of Rap1 by Epac2A, is essential primarily in the first phase of insulin secretion, not by triggering exocytosis per se but by facilitating the recruitment of the granules to the plasma membrane (Figure 2C) [45]. Full understanding of mechanisms by which cAMP regulates recruitment of granules via PKA and Epac2A is not yet known, however, a Golgi-derived microtubule nucleation process [154] as well as a microtubuleassociated protein termed syntabulin [155] that are both regulated by Epac2A may play a role. A recent study on Epac2A KO mice showed an attenuation of the first phase of insulin secretion, while the following second phase involved PKA signaling [45]. Some other studies reported the involvement of Epac2A also in the second phase of insulin secretion $[45,122,156]$. cAMP elevation was shown to stimulate Epac2A clustering at the site of docked granules, facilitating granule priming and exocytosis [157]. Epac2A/Rap signaling augments insulin secretion by increasing the size of the readily-releasable pool (RRP) of granules and by recruiting insulin granules to the plasma membrane [45]. These effects are not all Rap mediated, since Epac2A also interacts with Piccolo, Rim $2 \alpha$, and Rab3, all required for cAMP-regulated insulin granule exocytosis (Figure 2C) [86]. Epac2A, by complexing with the Rab3-interacting molecule Rim2, facilitates docking and priming of secretory granules [158]. Furthermore, granule acidification, a process important in granule priming, is influenced by Epac2A as well, as it regulates $\mathrm{Cl}^{-}$influx [159]. Epac2A also facilitates exocytosis of already docked and primed granules [159,160], at least partially through interactions with the t-SNARE component SNAP-25 via the cAMP-Epac2A $\backslash$ Rim2 pathway, which is essential for exocytosis [161]. Epac2A may also regulate exocytosis as a part of the Rim2-Munc13-1-SNARE protein-syntaxin complex that results in Munc13-1 mediated unfolding of syntaxin (Figure 2C). This complex was shown to be under the control of PKA as well [162]. PKA-dependent mechanism is also involved in exocytosis by sensitizing the secretory machinery to $\mathrm{Ca}^{2+}[163]$, increasing the number of highly $\mathrm{Ca}^{2+}$ sensitive pool (HCSP) of granules $[164,165]$ and increasing mobility and replenishment of the RRP and is therefore mainly responsible for the second phase of insulin secretion [160]. Along with the above mentioned syntaxin, SNAP-25 [161] and Snapin [49] appear to be exocytotic machinery proteins under dual control of both the PKA-dependent and the PKA-independent pathways (Figure 2C). PKA-dependent phosphorylation of Snapin thus 
appears to play a role in the merger of both cAMP stimulated pathways as well as in facilitation of exocytotic protein interactions and subsequent GSIS [49]. Taken together, these studies show that PKA and Epac2A, while not responsible for the triggering of exocytosis, contribute meaningfully to trafficking of insulin granules and facilitate their fusion with the plasma membrane.

\section{The Role of cAMP in Intercellular Coupling}

The pancreatic islets of Langerhans are multicellular micro-organs within which communication among a variety of cells with unique functions must occur to ensure proper control of metabolic homeostasis. The beta cells are the most abundant cell type within the islets, which, along with glucagon-producing $\alpha$-cells, somatostatin-producing $\delta$-cells, PP cells, and a minority of other cell types, constitute the endocrine component of the pancreas [166]. Islet cells communicate via direct electrical coupling through gap-junctions as well as by paracrine, autocrine, and juxtacrine signaling $[52,54,167,168]$. For beta cells, intercellular coupling established through gap junctions composed of Cx36 is particularly important, as it provides the necessary and the most important substrate for coordinated responses of the beta cell population, a prerequisite for the well-regulated secretion of insulin [57,62,72]. Specifically, gap junctions are a type of specialized membrane contacts that enable direct communication by allowing current-carrying ions and other small molecules to pass directly into the cytoplasm of adjacent cells, giving rise to propagating intercellular waves [5,55-58,169-173] [70,174-178]. Cx36 gap junction channels are sizeand charge-selective and favor the exchange of positively charged molecules at the expense of anionic molecules [179,180]. However, the cationic selectivity of Cx36 gap junctions is not absolute, as beta cells are able to exchange negatively charged molecules, such as phosphorylated glucose metabolites and nucleotides [52,181]. While the ionic coupling is the key intercellular mediator and extends to large regions of the islets, there is increasing evidence that metabolic coupling also plays a role in intra-islet communication but is more confined and encompasses smaller clusters of few beta cells [182-185]. All the compound coupling mechanisms along with beta cell heterogeneity underlie the complex functional connectivity patterns that are usually extracted from the recorded multicellular $\mathrm{Ca}^{2+}$ activity [70,174-178]. Noteworthy, disruptions of gap-junctional communication were found to impair synchronized beta cell responses and lead to dysregulated plasma insulin oscillations and to glucose intolerance $[59,61]$, as observed in numerous models of obesity and diabetes mellitus $[62,63,70,72,186]$. Moreover, prolonged exposure to high concentrations of glucose and fatty acids, as expected in diabetes, were found to downregulate Cx36 expression and disrupt the coherent patterns of intercellular synchronization [187,188], whereby some pharmacological agents seem to be able to at least partly repair the defective signaling pattern [70]. Gap junction coupling was also reported to be disrupted by proinflammatory cytokines, which also contribute to the decline in islet function during the pathogenesis of diabetes [189]. Along these lines, Cx36 gap junction coupling and its modulation are increasingly recognized as vital components in normal islet function $[73,190,191]$ and potentially viable targets to help restore insulin secretion in diabetes $[64,65,192]$.

How the neurohormonal signaling pathways influence gap-junctional communication and how they relate to the collective activity of beta cell networks are incompletely understood. First clues that cAMP affects cell-to-cell communication (Figure 2D) came from electrophysiological studies. Increasing intracellular cAMP concentration with forskolin in microdissected mouse islets enhanced conduction between couples of impaled beta cells by $24 \%$ [66]. In contrast to microdissection, in isolated islets, forskolin incubation failed to change the distribution of gap junction conductance of beta cells [193]. Finally, a third possible outcome of forskolin application on gap junction was reported in insulin-secreting cell lines where application of forskolin decreased Cx36 expression [187]. Despite these contradictory reports, only a few studies attempted to decipher the mechanism underlying the modulatory effect of cAMP on gap junctions. A chronic hyperlipidemia-induced down-regulation of Cx36 was reported to be associated with an overexpression of the 
inducible cAMP early repressor ICER-1 $\gamma$ [194,195], thereby implying a direct impact of the cAMP/PKA pathway on the gap junctional coupling. Moreover, additional evidence from other tissues, such as retinal AII amacrine cells or neurons of the inferior olive, corroborated the inhibitory role of PKA on Cx36 function $[68,74,196]$. Conversely, in rat myocardial cells, cAMP was found to enhance $C x 43$-mediated gap junctional coupling through both PKA and Epac2A pathways $[67,71]$, thereby substantiating further the complex and multifaceted role the incretin pathways play in multicellular systems.

Within the islets, the next line of evidence of the involvement of neurohormonal signaling pathways in cell-to-cell communication came from mice with ablation of Cx36. The logic behind this approach is that the incretin pathway (via PKA or Epac2A) increases insulin secretion, and if this effect is modulated in $\mathrm{C} \times 36 \mathrm{KO}$ mice, this would correlate the effect of either PKA or Epac2A to changes in gap junctional conduction. Along this line, the PKA specific agonist 6-Bnz-cAMP, but not the Epac2A specific agonist 8-Me-2-O-pCPTcAMP, produced a significant elevation of insulin secretion from Cx36 KO isolated islets compared to islets with intact intercellular connectivity [69]. This suggested that the PKA arm of the incretin pathway acts via a change in gap junction conductance, an observation that was also noticed in MIN-6 cell lines but with a contradictory effect of increasing insulin secretion when PKA was activated [197]. To complicate things even further, the modulatory effect of cAMP on gap junctions was studied only at low glucose (2 $\mathrm{mM})$ [69]. The authors proposed that cAMP functions to suppress insulin release only at basal blood glucose levels, and that this mechanism may serve as an alternative mechanism to the more commonly accepted path in which hyperpolarizing currents through gap junctions from less activated beta cells inhibit the more active beta cells. Furthermore, in human donor islets, by using a different methodological approach, an effect of cAMP on intercellular coupling was demonstrated by pharmacologically blocking gap junctions using $18-\alpha-$ glycyrrhetinic acid that resulted in desynchronization of the calcium response to GLP-1 and decreased insulin secretion [70]. Surprisingly, inhibiting gap junctional communication did not decrease insulin secretion in response to stimulation by $11 \mathrm{mM}$ glucose only, i.e., without GLP-1, pointing to a possible non-gap junctional action of gap junction blockers on the incretin signaling pathway. Moreover, it was shown that human islets respond to secretagogues in a highly coordinated manner guided by a network of interlinked cells, and lipotoxicity was shown to impair these responses. Notably, the deleterious effects of chronically elevated free fatty acid levels on the islet dynamics underlying insulin release were argued to be brought about through PKA- and cAMP-dependent inhibition of intercellular communication via gap junctions [70].

Very recently, Farnsworth et al. [73] examined the respective roles of PKA and Epac2A in beta cell-to-cell coupling very explicitly. In their study, in islets with decreased Cx36 coupling due to the action of pro-inflammatory cytokines, exendin-4, which increases cAMP, was found to overcome cytokine-induced dysfunction of islets, and restore the coupling. Their results showed that both neurohormonal signaling pathways play a role in mediating cAMP regulation of Cx36 in islets but in a different manner. PKA was suggested to regulate $\mathrm{C} \times 36$ coupling via fast mechanisms, such as $\mathrm{C} \times 36$ phosphorylation and channel gating, whereas Epac2A was reported to modulate Cx36 coupling via slower mechanisms, such as trafficking, assembly, or turnover of Cx36 channels. These concepts are presented in Figure 2D, where it is illustrated that PKA regulates Cx36 coupling via gating of gap junction channel conductance, whereas Epac2A operates on slower temporal scales by regulating Cx36 trafficking, gap junction assembly, or Cx36 endocytosis in beta cells. Further investigations will be needed to assess these ideas and the underlying mechanisms in more detail, but, in general, they go well in hand with what was reported in other systems $[67,68,72,73,198]$. 
Finally, in our very recent study, we investigated explicitly how cAMP-mediated amplification affected the collective beta cell activity within the islets [199]. Our results showed that the activation of cAMP signaling did not only profoundly increase beta cell activity but also enhanced synchronicity and the coordination of intercellular signals. To provide a clear demonstration of this behavior, we present in Figure 3 an exemplary recording of an islet that was stimulated with $9 \mathrm{mM}$ glucose and subsequently with $10 \mu \mathrm{M}$ forskolin. The increase in cytosolic cAMP caused by forskolin evoked a more than a two-fold increase in the oscillation frequency, a slight decrease in the duration of oscillations, and an increase in the level of synchronization, reflected by the average correlation coefficient. The raster plots in Figure 3E,F indicate that, after the application of forskolin, the multicellular dynamics were dominated by global and well-aligned $\mathrm{Ca}^{2+}$ waves, while under stimulation with glucose only, the activity patterns were more erratic. To assess the collective activity in further detail, we constructed functional connectivity networks [178] separately for the stimulation with glucose only and glucose with additional forskolin. The results presented in Figure 3G,H indicate that increased levels of cAMP led to a denser and a more integral network (Figure $3 \mathrm{H}$ ), thereby signifying a higher degree of synchronization between beta cells when compared to glucose stimulation only (Figure 3G). This is well in agreement with our previous results, where, in control experiments with prolonged glucose stimulation only, synchronized behavior diminished with time, but the activation of cAMP prevented this effect and enhanced the degree of beta cell synchronicity [199]. Most importantly, performing the same set of experiments with Epac2A KO mice, stimulation with forskolin restored the functional network integrity only partly. These observations imply that both arms of the neurohormonal amplifying pathway play a role by shaping the collective beta cell activity in islets and parallel in part with the recent findings by Farnsworth et al. [166], where increased cAMP was also identified as a promotor for intercellular coupling. Moreover, the absence of Epac2A, which might be associated with impaired connexon trafficking pathways [166], apparently hinders the beta cells from Epac2A KO mice to fully exploit the positive effects that increased cAMP has on the beta cell network activity. Nevertheless, the precise roles that the different arms of the neurohormonal signaling pathway play in the functionality of beta cell networks and the question of to what extent the effect of cAMP on insulin secretion can be attributed to its impact on intercellular coupling remain to be elucidated in future studies [73]. 

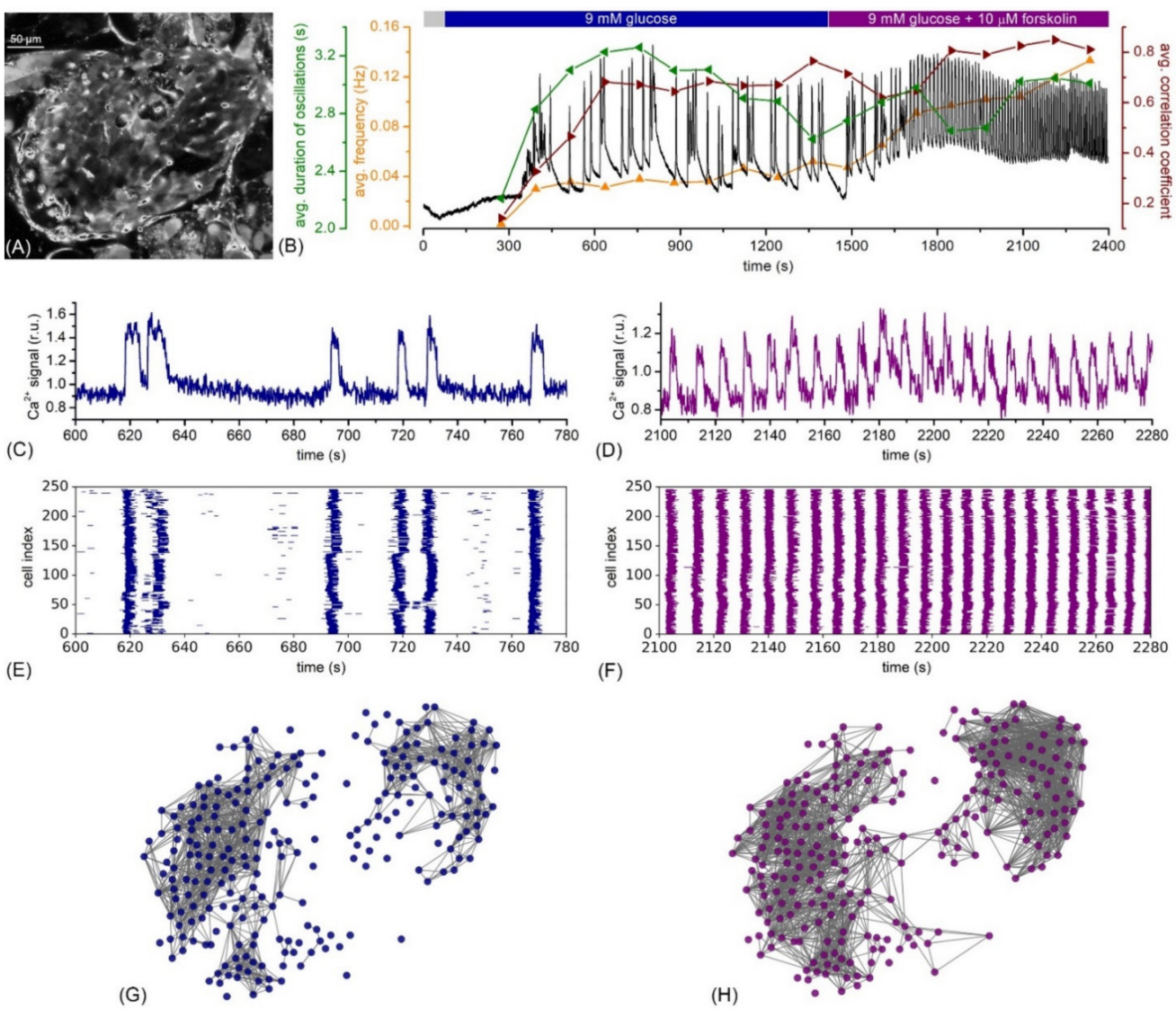

Figure 3. Multicellular beta cell activity under stimulatory glucose levels and the additional activation of the neurohormonal amplifying pathways by forskolin. (A) Confocal image of an islet of Langerhans within the tissue slice with well stained cells using fluorescent calcium dye Calbryte 520AM; (B) average $\mathrm{Ca}^{2+}$ signal calculated based on all beta cells in the islet (black line), the temporal evolution of the frequency (orange), the duration of oscillations (green), and the average correlation coefficient (red). For the calculation of signaling parameters, we used a sliding window of 3 min and a window overlap of $1 \mathrm{~min}$. The stimulation protocol is visualized on the top of the panel, whereby the grey rectangle signifies substimulatory $6 \mathrm{mM}$ glucose concentration; $(\mathbf{C}-\mathbf{H})$ recorded traces from an exemplary cell $(\mathbf{C}, \mathbf{D})$, raster plots of binarized $\mathrm{Ca}^{2+}$ activity of all selected cells in the islet $(\mathbf{E}, \mathbf{F})$, and the corresponding functional beta cell networks $(\mathbf{G}, \mathbf{H})$ under stimulation with $9 \mathrm{mM}$ glucose $(\mathbf{C}, \mathbf{E}, \mathbf{G})$ and with $9 \mathrm{mM}$ glucose plus $10 \mu \mathrm{M}$ forskolin $(\mathbf{D}, \mathbf{F}, \mathbf{H})$. The multicellular $\mathrm{Ca}^{2+}$ activity of beta cells was captured by means of confocal laser scanning microscopy in an acute pancreatic tissue slice (see Refs. [58,200] for methodological details).

\section{The Role of cAMP during the Development of Insulin Resistance}

In insulin resistance, compensatory beta cell adaptation ensures increased insulin secretion, which is usually able to sustain normoglycemia for long periods of time [201,202]. However, when beta cell compensation fails to meet increasing insulin demands imposed by insulin resistance, glucose intolerance first becomes apparent as mild and later overt hyperglycemia that characterizes a full-blown T2DM [203]. Several high-quality studies established that the elevated plasma insulin levels in complete compensation (hyperinsulinemia and normoglycemia) or in partially compensated prediabetic state (hyperinsulinemia and mild hyperglycemia) are related with morphological adaptation in the form of an increased beta cell mass [204]. Importantly, the evidence is not unanimous, and some reports reported only moderate [205] or no increases in beta cell mass in insulin resistance compared with controls [206]. It was demonstrated that GLP-1 enhances beta cell survival by activating beta cell proliferation and differentiation and inhibiting apoptosis. The underlying mechanism is relatively complex, involving a PKA-mediated translocation of a protein complex composed of a transducer of regulated CREB activity-2 (TORC2) and a cAMP-response element binding protein (CREB) into the nucleus, where it induces 
transcription of genes that are involved in beta cell survival. It remains to be clarified whether this is solely a PKA-mediated effect [207]. The GLP-1 enhancing effect was indirectly corroborated in an animal model of insulin resistance, where GLP-1 treatment increased the amount of insulin secreted following a glucose load [208] (for review on (dis)advantages of chemically inducing insulin resistance in animal models, see [209]). Importantly, later, during worsening of insulin resistance and glucose intolerance, beta cell mass was typically decreased [210]. In a diet-induced mouse model of diabetes supplemented with streptozotocin (STZ) administration, chronic GLP-1R stimulation partially rescued the decrease in beta cell mass [211], confirming the role of cAMP in morphological adaptation, even in the setting of decompensated diabetes.

In stark contrast, comparatively few studies addressed the role of beta cell functional adaptation in the compensatory response to insulin resistance, and thus changes in beta cell SSC, and intercellular coupling remain poorly characterized in obesity [212-214]. Additionally, most data about beta cell functional adaptation come from isolated beta cells $[213,214]$, which are unable to fully capture the normal physiological scenario compared with isolated islets $[215,216]$ or tissue slices $[58,171]$. In a genetic model of obesity $(o b / o b)$ characterized by hyperinsulinemia and moderate hyperglycemia, beta cells displayed enhanced mitochondrial function and electrical activity, left shift in sensitivity and a preponderance of slow $\left[\mathrm{Ca}^{2+}\right]_{\mathrm{IC}}$ oscillations, increased GSIS, and reduction in beta cell coupling [188]. Similarly, in high fat diet (HFD)-induced insulin resistant mice that were hyperinsulinemic and normoglycemic, insulin gene expression and GSIS were increased, and glucose-induced $\left[\mathrm{Ca}^{2+}\right]_{\mathrm{IC}}$ and exocytotic responses were enhanced [217]. Similarly to the decrease in beta cell mass, beta cell function starts to deteriorate once overt type 2 diabetes mellitus develops. Beta cell decompensation encompasses oxidative and endoplasmic reticulum (ER) stress, dedifferentiation, and lower expression of GLUT2, glucokinase, as well as anomalies in $\mathrm{ER} \mathrm{Ca}^{2+}$ mobilization. Additionally, beta cell connectivity was shown to deteriorate during progression of T2DM, and this might be one of the earliest defects $[65,72,203]$. These alterations are believed to be a consequence of chronic hyperglycemia, hyperlipidemia, and a proinflammatory metabolic state $[64,70,177,189,218]$.

Limited data are available to explain which aspects of beta cell functional adaptation depend on the GLP-1 receptor signaling cascade, cAMP, and specifically on PKA and Epac2A. Epac2A seems to play a role in potentiation of GSIS under conditions of increased demand for insulin, e.g., in insulin resistance, such as during obesity [219]. Studies employing HFD in the Epac2A KO mice to induce insulin resistance implicated that Epac2A ablation results in increased body weight, impaired glucose tolerance [50,51], and decreased GSIS during 4 weeks of a HFD diet intervention compared with control mice on the same diet [50]. Surprisingly, another study reported an increase in GSIS during 8 weeks of HFD diet in Epac2A KO mice compared with control mice on the same diet [51]. A mechanistic explanation for how Epac2A could bring about an improvement in GSIS during an ipGTT in insulin resistance is not available at the moment, but it was suggested that, under these conditions, glucose-induced production of cAMP and Epac2A activation might become operative [220]. However, experimental verification is missing as well as an explanation for the differential effect on GSIS in Epac2A KO mice on HFD at 4 and 8 weeks. To complicate matters even further, it was demonstrated that the Epac2A-dependent GSIS potentiation also involves the brain-islet axis. The neuropeptide Orexin A secreted from the lateral hypothalamic area potentiated GSIS in vitro, and this effect was blocked in Epac2A-deficient mice [221]. Paradoxically, the plasma levels of OXA were decreased in rodent models of T2DM [222,223] and in obese women [224]. To the best of our knowledge, a single study addressed the role of PKA in the setting of insulin resistance. Disruption of the protein PKA inhibitor beta (PKIB), an effective inhibitor of PKA activity, improved glucose sensitivity and GSIS in a 20-week HFD-induced mouse model [225], suggesting a PKA-potentiating effect on GSIS. To our knowledge, there are no data on the roles of Epac2A and PKA in changes of $\left[\mathrm{Ca}^{2+}\right]_{\mathrm{IC}}$ oscillations, sensitivity of the exocytotic machinery, or intercellular coupling during diet-induced T2DM. A single study demonstrated that, 
in human islets, cAMP stimulates synchronous $\left[\mathrm{Ca}^{2+}\right]_{\text {IC }}$ increases that augment insulin secretion, and the signals become asynchronous with an accompanying reduction in insulin secretion in lipotoxic conditions [70].

Finally, a role of Epac2A was implicated in hypersecretion of insulin observed in combination therapies for T2DM treatment [226]. Coadministration of liraglutide (a GLP$1 \mathrm{R}$ agonist) and glimepiride (SU) resulted in increased blood glucose during OGTT in Epac2A KO mice on HFD. These results indicate that the glucose-lowering effect of the combination of liraglutide and glimepiride is diminished in Epac2A KO mice. Thus, Epac2A seems to play a role in insulin secretion induced by the combination of an incretin and $\mathrm{SU}$, especially in a model of diet-induced obesity, and may provide an explanation for the SU-dependent difference in the incidence rate of hypoglycemia observed in combination therapies. In sum, while cAMP tends to have a positive role in beta cell morphological and functional adaptation to insulin resistance, the relative lack of data in this important field warrants further studies to help us understand the underlying mechanisms.

\section{Conclusions}

Concentrating on a possible role of cAMP in general and its two main signaling arms in specific, our journey led us from the most proximal membrane potential step in the SSC cascade, via the central $\left[\mathrm{Ca}^{2+}\right]_{\mathrm{IC}}$ changes, to the most distal event, exocytosis. We also addressed the aspect of intercellular coupling and the relevance in vivo. It is quite self-evident that our knowledge about the role of cAMP is limited and biased due to the influence of historically and currently available electro- and optophysiological tools, pharmacological agents, development of specific animal models, and access to human tissue, among many other factors. Since a deeper insight into the normal intra- and intercellular coupling in beta cells and the role played by cAMP is central for a better understanding of the natural history of diabetes mellitus as well as for prevention, finding new targets, and developing new pharmacological approaches, we firmly believe that future studies will help push the frontiers of knowledge and truly hope that our review helped identify some most needed next steps.

Funding: This research was funded by the SLOVENIAN RESEARCH AGENCY, grant number P3-0396, I0-0029, N3-0048, N3-0133, and J3-9289.

Conflicts of Interest: The authors declare no conflict of interest.

\section{References}

1. IDF Diabetes Atlas, 9th ed.; International Diabetes Federation: Brussels, Belgium, 2019.

2. Stratton, I.M.; Adler, A.I.; Neil, H.A.; Matthews, D.R.; Manley, S.E.; Cull, C.A.; Hadden, D.; Turner, R.C.; Holman, R.R. Association of glycaemia with macrovascular and microvascular complications of type 2 diabetes (UKPDS 35): Prospective observational study. BMJ 2000, 321, 405-412. [CrossRef]

3. Weyer, C.; Bogardus, C.; Mott, D.M.; Pratley, R.E. The natural history of insulin secretory dysfunction and insulin resistance in the pathogenesis of type 2 diabetes mellitus. J. Clin. Investig. 1999, 104, 787-794. [CrossRef] [PubMed]

4. Seino, S.; Takahashi, H.; Takahashi, T.; Shibasaki, T. Treating diabetes today: A matter of selectivity of sulphonylureas. Diabetes Obes. Metab. 2012, 14, 9-13. [CrossRef] [PubMed]

5. Skelin Klemen, M.; Dolenšek, J.; Slak Rupnik, M.; Stožer, A. The triggering pathway to insulin secretion: Functional similarities and differences between the human and the mouse $\beta$ cells and their translational relevance. Islets 2017, 9, 109-139. [CrossRef]

6. Henquin, J.C. Triggering and amplifying pathways of regulation of insulin secretion by glucose. Diabetes 2000, 49, 1751-1760. [CrossRef] [PubMed]

7. Henquin, J.-C. The dual control of insulin secretion by glucose involves triggering and amplifying pathways in $\beta$-cells. Diabetes Res. Clin. Pract. 2011, 93, S27-S31. [CrossRef]

8. Sturgess, N.C.; Ashford, M.L.; Cook, D.L.; Hales, C.N. The sulphonylurea receptor may be an ATP-sensitive potassium channel. Lancet 1985, 2, 474-475. [CrossRef]

9. De Wet, H.; Proks, P. Molecular action of sulphonylureas on KATP channels: A real partnership between drugs and nucleotides. Biochem. Soc. Trans. 2015, 43, 901-907. [CrossRef]

10. Proks, P.; de Wet, H.; Ashcroft, F.M. Molecular mechanism of sulphonylurea block of K(ATP) channels carrying mutations that impair ATP inhibition and cause neonatal diabetes. Diabetes 2013, 62, 3909-3919. [CrossRef] 
11. Pipatpolkai, T.; Usher, S.; Stansfeld, P.J.; Ashcroft, F.M. New insights into KATP channel gene mutations and neonatal diabetes mellitus. Nat. Rev. Endocrinol. 2020, 16, 378-393. [CrossRef]

12. Efanova, I.B.; Zaitsev, S.V.; Zhivotovsky, B.; Kohler, M.; Efendic, S.; Orrenius, S.; Berggren, P.O. Glucose and tolbutamide induce apoptosis in pancreatic beta-cells. A process dependent on intracellular $\mathrm{Ca}^{2+}$ concentration. J. Biol. Chem. 1998, 273, 33501-33507. [CrossRef]

13. Maedler, K.; Carr, R.D.; Bosco, D.; Zuellig, R.A.; Berney, T.; Donath, M.Y. Sulfonylurea induced beta-cell apoptosis in cultured human islets. J. Clin. Endocrinol. Metab. 2005, 90, 501-506. [CrossRef]

14. Elrick, H.; Stimmler, L.; Hlad, C.J., Jr.; Arai, Y. Plasma Insulin Response to Oral and Intravenous Glucose Administration. J. Clin. Endocrinol. Metab. 1964, 24, 1076-1082. [CrossRef]

15. McIntyre, N.; Holdsworth, C.D.; Turner, D.S. New Interpretation of Oral Glucose Tolerance. Lancet 1964, 2, 20-21. [CrossRef]

16. Jones, B.; Bloom, S.R.; Buenaventura, T.; Tomas, A.; Rutter, G.A. Control of insulin secretion by GLP-1. Peptides 2018, 100, 75-84. [CrossRef]

17. Nauck, M.A.; Meier, J.J. Incretin hormones: Their role in health and disease. Diabetes Obes. Metab. 2018, 20, 5-21. [CrossRef]

18. Nauck, M.A.; Meier, J.J. The incretin effect in healthy individuals and those with type 2 diabetes: Physiology, pathophysiology, and response to therapeutic interventions. Lancet Diabetes Endocrinol. 2016, 4, 525-536. [CrossRef]

19. Gasbjerg, L.S.; Bergmann, N.C.; Stensen, S.; Christensen, M.B.; Rosenkilde, M.M.; Holst, J.J.; Nauck, M.; Knop, F.K. Evaluation of the incretin effect in humans using GIP and GLP-1 receptor antagonists. Peptides 2020, 125, 170183. [CrossRef]

20. Holst, J.J. The incretin system in healthy humans: The role of GIP and GLP-1. Metabolism 2019, 96, 46-55. [CrossRef]

21. Dupre, J.; Ross, S.A.; Watson, D.; Brown, J.C. Stimulation of insulin secretion by gastric inhibitory polypeptide in man. J. Clin. Endocrinol. Metab. 1973, 37, 826-828. [CrossRef]

22. Herrmann, C.; Goke, R.; Richter, G.; Fehmann, H.C.; Arnold, R.; Goke, B. Glucagon-like peptide-1 and glucose-dependent insulin-releasing polypeptide plasma levels in response to nutrients. Digestion 1995, 56, 117-126. [CrossRef]

23. Vollmer, K.; Holst, J.J.; Baller, B.; Ellrichmann, M.; Nauck, M.A.; Schmidt, W.E.; Meier, J.J. Predictors of incretin concentrations in subjects with normal, impaired, and diabetic glucose tolerance. Diabetes 2008, 57, 678-687. [CrossRef]

24. Takeda, J.; Seino, Y.; Tanaka, K.; Fukumoto, H.; Kayano, T.; Takahashi, H.; Mitani, T.; Kurono, M.; Suzuki, T.; Tobe, T.; et al. Sequence of an intestinal cDNA encoding human gastric inhibitory polypeptide precursor. Proc. Nat. Acad. Sci. USA 1987, 84, 7005-7008. [CrossRef]

25. Mayo, K.E.; Miller, L.J.; Bataille, D.; Dalle, S.; Goke, B.; Thorens, B.; Drucker, D.J. International Union of Pharmacology. XXXV. The glucagon receptor family. Pharmacol. Rev. 2003, 55, 167-194. [CrossRef] [PubMed]

26. Mortensen, K.; Christensen, L.L.; Holst, J.J.; Orskov, C. GLP-1 and GIP are colocalized in a subset of endocrine cells in the small intestine. Regul. Pept. 2003, 114, 189-196. [CrossRef]

27. Nauck, M.A.; Heimesaat, M.M.; Orskov, C.; Holst, J.J.; Ebert, R.; Creutzfeldt, W. Preserved incretin activity of glucagon-like peptide 1 [7-36 amide] but not of synthetic human gastric inhibitory polypeptide in patients with type-2 diabetes mellitus. J. Clin. Investig. 1993, 91, 301-307. [CrossRef] [PubMed]

28. Toft-Nielsen, M.B.; Damholt, M.B.; Madsbad, S.; Hilsted, L.M.; Hughes, T.E.; Michelsen, B.K.; Holst, J.J. Determinants of the impaired secretion of glucagon-like peptide-1 in type 2 diabetic patients. J. Clin. Endocrinol. Metab. 2001, 86, 3717-3723. [CrossRef] [PubMed]

29. Toft-Nielsen, M.B.; Madsbad, S.; Holst, J.J. Determinants of the effectiveness of glucagon-like peptide-1 in type 2 diabetes. J. Clin. Endocrinol. Metab. 2001, 86, 3853-3860. [CrossRef] [PubMed]

30. Gutniak, M.; Orskov, C.; Holst, J.J.; Ahren, B.; Efendic, S. Antidiabetogenic effect of glucagon-like peptide-1 (7-36)amide in normal subjects and patients with diabetes mellitus. N. Engl. J. Med. 1992, 326, 1316-1322. [CrossRef]

31. Holz, G.G.; Chepurny, O.G. Glucagon-like peptide-1 synthetic analogs: New therapeutic agents for use in the treatment of diabetes mellitus. Curr. Med. Chem. 2003, 10, 2471-2483. [CrossRef]

32. Mietlicki-Baase, E.G.; Liberini, C.G.; Workinger, J.L.; Bonaccorso, R.L.; Borner, T.; Reiner, D.J.; Koch-Laskowski, K.; McGrath, L.E.; Lhamo, R.; Stein, L.M.; et al. A vitamin B12 conjugate of exendin-4 improves glucose tolerance without associated nausea or hypophagia in rodents. Diabetes Obes. Metab. 2018, 20, 1223-1234. [CrossRef]

33. Seino, S.; Shibasaki, T.; Minami, K. Dynamics of insulin secretion and the clinical implications for obesity and diabetes. J. Clin. Investig. 2011, 121, 2118-2125. [CrossRef]

34. Scrocchi, L.A.; Brown, T.J.; MaClusky, N.; Brubaker, P.L.; Auerbach, A.B.; Joyner, A.L.; Drucker, D.J. Glucose intolerance but normal satiety in mice with a null mutation in the glucagon-like peptide 1 receptor gene. Nat. Med. 1996, 2, 1254-1258. [CrossRef]

35. Salehi, M.; Vahl, T.P.; D'Alessio, D.A. Regulation of islet hormone release and gastric emptying by endogenous glucagon-like peptide 1 after glucose ingestion. J. Clin. Endocrinol. Metab. 2008, 93, 4909-4916. [CrossRef]

36. Salehi, M.; Aulinger, B.; D'Alessio, D.A. Effect of glycemia on plasma incretins and the incretin effect during oral glucose tolerance test. Diabetes 2012, 61, 2728-2733. [CrossRef]

37. Aulinger, B.A.; Vahl, T.P.; Wilson-Perez, H.E.; Prigeon, R.L.; D'Alessio, D.A. beta-Cell Sensitivity to GLP-1 in Healthy Humans Is Variable and Proportional to Insulin Sensitivity. J. Clin. Endocrinol. Metab. 2015, 100, 2489-2496. [CrossRef]

38. Kjems, L.L.; Holst, J.J.; Volund, A.; Madsbad, S. The influence of GLP-1 on glucose-stimulated insulin secretion: Effects on beta-cell sensitivity in type 2 and nondiabetic subjects. Diabetes 2003, 52, 380-386. [CrossRef] 
39. Muscelli, E.; Mari, A.; Casolaro, A.; Camastra, S.; Seghieri, G.; Gastaldelli, A.; Holst, J.J.; Ferrannini, E. Separate impact of obesity and glucose tolerance on the incretin effect in normal subjects and type 2 diabetic patients. Diabetes 2008, 57, 1340-1348. [CrossRef]

40. Charles, M.A.; Fanska, R.; Schmid, F.G.; Forsham, P.H.; Grodsky, G.M. Adenosine 3', $5^{\prime}$-monophosphate in pancreatic islets: Glucose-induced insulin release. Science 1973, 179, 569-571. [CrossRef]

41. Charles, M.A.; Lawecki, J.; Pictet, R.; Grodsky, G.M. Insulin secretion. Interrelationships of glucose, cyclic adenosine 3:5monophosphate, and calcium. J. Biol. Chem. 1975, 250, 6134-6140. [CrossRef]

42. Saikia, M.; Holter, M.M.; Donahue, L.R.; Lee, I.S.; Zheng, Q.C.; Wise, J.L.; Todero, J.E.; Phuong, D.J.; Garibay, D.; Coch, R.; et al. GLP-1 receptor signaling increases PCSK1 and $\beta$ cell features in human $\alpha$ cells. JCI Insight 2021, 6. [CrossRef] [PubMed]

43. Tengholm, A.; Gylfe, E. cAMP signalling in insulin and glucagon secretion. Diabetes Obes. Metab. 2017, 19, 42-53. [CrossRef] [PubMed]

44. Adame-García, S.R.; Cervantes-Villagrana, R.D.; Orduña-Castillo, L.B.; Del Rio, J.C.; Gutkind, J.S.; Reyes-Cruz, G.; Taylor, S.S.; Vázquez-Prado, J. cAMP-dependent activation of the Rac guanine exchange factor P-REX1 by type I protein kinase A (PKA) regulatory subunits. J. Biol. Chem. 2019, 294, 2232-2246. [CrossRef] [PubMed]

45. Shibasaki, T.; Takahashi, H.; Miki, T.; Sunaga, Y.; Matsumura, K.; Yamanaka, M.; Zhang, C.; Tamamoto, A.; Satoh, T.; Miyazaki, J.-i.; et al. Essential role of Epac2/Rap1 signaling in regulation of insulin granule dynamics by cAMP. Proc. Natl. Acad. Sci. USA 2007, 104, 19333-19338. [CrossRef] [PubMed]

46. Zhang, C.-L.; Katoh, M.; Shibasaki, T.; Minami, K.; Sunaga, Y.; Takahashi, H.; Yokoi, N.; Iwasaki, M.; Miki, T.; Seino, S. The cAMP Sensor Epac2 Is a Direct Target of Antidiabetic Sulfonylurea Drugs. Science 2009, 325, 607-610. [CrossRef] [PubMed]

47. Takahashi, T.; Shibasaki, T.; Takahashi, H.; Sugawara, K.; Ono, A.; Inoue, N.; Furuya, T.; Seino, S. Antidiabetic sulfonylureas and cAMP cooperatively activate Epac2A. Sci. Signal 2013, 6, ra94. [CrossRef]

48. Seino, S.; Sugawara, K.; Yokoi, N.; Takahashi, H. beta-Cell signalling and insulin secretagogues: A path for improved diabetes therapy. Diabetes Obes. Metab. 2017, 19, 22-29. [CrossRef]

49. Song, W.-J.; Seshadri, M.; Ashraf, U.; Mdluli, T.; Mondal, P.; Keil, M.; Azevedo, M.; Kirschner, L.S.; Stratakis, C.A.; Hussain, M.A. Snapin mediates incretin action and augments glucose-dependent insulin secretion. Cell Metab. 2011, 13, 308-319. [CrossRef]

50. Song, W.J.; Mondal, P.; Li, Y.; Lee, S.E.; Hussain, M.A. Pancreatic beta-cell response to increased metabolic demand and to pharmacologic secretagogues requires EPAC2A. Diabetes 2013, 62, 2796-2807. [CrossRef]

51. Hwang, M.; Go, Y.; Park, J.H.; Shin, S.K.; Song, S.E.; Oh, B.C.; Im, S.S.; Hwang, I.; Jeon, Y.H.; Lee, I.K.; et al. Epac2a-null mice exhibit obesity-prone nature more susceptible to leptin resistance. Int. J. Obes. 2017, 41, 279-288. [CrossRef]

52. Jain, R.; Lammert, E. Cell-cell interactions in the endocrine pancreas. Diabetes Obes. Metab. 2009, 11, 159-167. [CrossRef]

53. Meda, P. The in vivo beta-to-beta-cell chat room: Connexin connections matter. Diabetes 2012, 61, 1656-1658. [CrossRef]

54. Weitz, J.; Menegaz, D.; Caicedo, A. Deciphering the Complex Communication Networks That Orchestrate Pancreatic Islet Function. Diabetes 2021, 70, 17-26. [CrossRef]

55. Aslanidi, O.V.; Mornev, O.A.; Skyggebjerg, O.; Arkhammar, P.; Thastrup, O.; Sørensen, M.P.; Christiansen, P.L.; Conradsen, K.; Scott, A.C. Excitation Wave Propagation as a Possible Mechanism for Signal Transmission in Pancreatic Islets of Langerhans. Biophys. J. 2001, 80, 1195-1209. [CrossRef]

56. Benninger, R.K.; Zhang, M.; Head, W.S.; Satin, L.S.; Piston, D.W. Gap junction coupling and calcium waves in the pancreatic islet. Biophys. J. 2008, 95, 5048-5061. [CrossRef]

57. Bosco, D.; Haefliger, J.-A.; Meda, P. Connexins: Key Mediators of Endocrine Function. Physiol. Rev. 2011, 91, 1393-1445. [CrossRef]

58. Stožer, A.; Dolenšek, J.; Rupnik, M.S. Glucose-Stimulated Calcium Dynamics in Islets of Langerhans in Acute Mouse Pancreas Tissue Slices. PLoS ONE 2013, 8, e54638. [CrossRef]

59. Ravier, M.A.; Güldenagel, M.; Charollais, A.; Gjinovci, A.; Caille, D.; Söhl, G.; Wollheim, C.B.; Willecke, K.; Henquin, J.-C.; Meda, P. Loss of Connexin36 Channels Alters $\beta$-Cell Coupling, Islet Synchronization of Glucose-Induced Ca ${ }^{2+}$ and Insulin Oscillations, and Basal Insulin Release. Diabetes 2005, 54, 1798-1807. [CrossRef]

60. Hamelin, R.; Allagnat, F.; Haefliger, J.A.; Meda, P. Connexins, diabetes and the metabolic syndrome. Curr. Protein Pept. Sci. 2009, 10, 18-29. [CrossRef]

61. Head, W.S.; Orseth, M.L.; Nunemaker, C.S.; Satin, L.S.; Piston, D.W.; Benninger, R.K. Connexin-36 gap junctions regulate in vivo first- and second-phase insulin secretion dynamics and glucose tolerance in the conscious mouse. Diabetes 2012, 61, 1700-1707. [CrossRef]

62. Benninger, R.K.; Piston, D.W. Cellular communication and heterogeneity in pancreatic islet insulin secretion dynamics. Trends Endocrinol. Metab. TEM 2014. [CrossRef]

63. Satin, L.S.; Butler, P.C.; Ha, J.; Sherman, A.S. Pulsatile insulin secretion, impaired glucose tolerance and type 2 diabetes. Mol. Asp. Med. 2015, 42, 61-77. [CrossRef]

64. Farnsworth, N.L.; Hemmati, A.; Pozzoli, M.; Benninger, R.K. Fluorescence recovery after photobleaching reveals regulation and distribution of connexin36 gap junction coupling within mouse islets of Langerhans. J. Physiol. 2014, 592, 4431-4446. [CrossRef]

65. Rutter, G.A.; Hodson, D.J. Beta cell connectivity in pancreatic islets: A type 2 diabetes target? Cell. Mol. Life Sci. CMLS 2015, 72, 453-467. [CrossRef]

66. Mears, D.; Sheppard, N.F.; Atwater, I.; Rojas, E. Magnitude and modulation of pancreatic $\beta$-cell gap junction electrical conductance in situ. J. Membr. Biol. 1995, 146, 163-176. [CrossRef] 
67. Somekawa, S.; Fukuhara, S.; Nakaoka, Y.; Fujita, H.; Saito, Y.; Mochizuki, N. Enhanced functional gap junction neoformation by protein kinase A-dependent and Epac-dependent signals downstream of cAMP in cardiac myocytes. Circ. Res. 2005, 97, 655-662. [CrossRef]

68. Urschel, S.; Hoher, T.; Schubert, T.; Alev, C.; Sohl, G.; Worsdorfer, P.; Asahara, T.; Dermietzel, R.; Weiler, R.; Willecke, K. Protein kinase A-mediated phosphorylation of connexin36 in mouse retina results in decreased gap junctional communication between AII amacrine cells. J. Biol. Chem. 2006, 281, 33163-33171. [CrossRef]

69. Benninger, R.K.P.; Head, W.S.; Zhang, M.; Satin, L.S.; Piston, D.W. Gap junctions and other mechanisms of cell-cell communication regulate basal insulin secretion in the pancreatic islet. J. Physiol. 2011, 589, 5453-5466. [CrossRef] [PubMed]

70. Hodson, D.J.; Mitchell, R.K.; Bellomo, E.A.; Sun, G.; Vinet, L.; Meda, P.; Li, D.; Li, W.H.; Bugliani, M.; Marchetti, P.; et al. Lipotoxicity disrupts incretin-regulated human beta cell connectivity. J. Clin. Investig. 2013, 123, 4182-4194. [CrossRef] [PubMed]

71. Lee, T.-M.; Lin, S.-Z.; Chang, N.-C. Both PKA and Epac pathways mediate N-acetylcysteine-induced Connexin43 preservation in rats with myocardial infarction. PLoS ONE 2013, 8, e71878. [CrossRef] [PubMed]

72. Farnsworth, N.L.; Benninger, R.K. New insights into the role of connexins in pancreatic islet function and diabetes. FEBS Lett. 2014, 588, 1278-1287. [CrossRef]

73. Farnsworth, N.L.; Walter, R.; Piscopio, R.A.; Schleicher, W.E.; Benninger, R.K.P. Exendin-4 overcomes cytokine-induced decreases in gap junction coupling via protein kinase A and Epac2 in mouse and human islets. J. Physiol. 2019, 597, 431-447. [CrossRef]

74. Bazzigaluppi, P.; Isenia, S.C.; Haasdijk, E.D.; Elgersma, Y.; De Zeeuw, C.I.; van der Giessen, R.S.; de Jeu, M.T.G. Modulation of Murine Olivary Connexin 36 Gap Junctions by PKA and CaMKII. Front. Cell Neurosci. 2017, 11, 397. [CrossRef]

75. Ni, Q.; Ganesan, A.; Aye-Han, N.N.; Gao, X.; Allen, M.D.; Levchenko, A.; Zhang, J. Signaling diversity of PKA achieved via a $\mathrm{Ca}^{2+}$-cAMP-PKA oscillatory circuit. Nat. Chem. Biol. 2011, 7, 34-40. [CrossRef]

76. Drucker, D.J.; Nauck, M.A. The incretin system: Glucagon-like peptide-1 receptor agonists and dipeptidyl peptidase-4 inhibitors in type 2 diabetes. Lancet 2006, 368, 1696-1705. [CrossRef]

77. Dessauer, C.W. Adenylyl cyclase-A-kinase anchoring protein complexes: The next dimension in cAMP signaling. Mol. Pharm. 2009, 76, 935-941. [CrossRef]

78. Tenner, B.; Getz, M.; Ross, B.; Ohadi, D.; Bohrer, C.H.; Greenwald, E.; Mehta, S.; Xiao, J.; Rangamani, P.; Zhang, J. Spatially compartmentalized phase regulation of a Ca(2+)-cAMP-PKA oscillatory circuit. eLife 2020, 9, e55013. [CrossRef]

79. Inagaki, N.; Gonoi, T.; Clement, J.P.t.; Namba, N.; Inazawa, J.; Gonzalez, G.; Aguilar-Bryan, L.; Seino, S.; Bryan, J. Reconstitution of IKATP: An inward rectifier subunit plus the sulfonylurea receptor. Science 1995, 270, 1166-1170. [CrossRef]

80. Aguilar-Bryan, L.; Bryan, J.; Nakazaki, M. Of Mice and Men: KATP Channels and Insulin Secretion. Recent. Prog. Horm. Res. 2001, 56, 47-68. [CrossRef]

81. Speier, S.; Yang, S.B.; Sroka, K.; Rose, T.; Rupnik, M. KATP-channels in beta-cells in tissue slices are directly modulated by millimolar ATP. Mol. Cell. Endocrinol. 2005, 230, 51-58. [CrossRef]

82. Light, P.E.; Manning Fox, J.E.; Riedel, M.J.; Wheeler, M.B. Glucagon-like peptide-1 inhibits pancreatic ATP-sensitive potassium channels via a protein kinase A- and ADP-dependent mechanism. Mol. Endocrinol. 2002, 16, 2135-2144. [CrossRef] [PubMed]

83. Beguin, P.; Nagashima, K.; Nishimura, M.; Gonoi, T.; Seino, S. PKA-mediated phosphorylation of the human K(ATP) channel: Separate roles of Kir6.2 and SUR1 subunit phosphorylation. EMBO J. 1999, 18, 4722-4732. [CrossRef] [PubMed]

84. Kang, G.; Chepurny, O.G.; Malester, B.; Rindler, M.J.; Rehmann, H.; Bos, J.L.; Schwede, F.; Coetzee, W.A.; Holz, G.G. cAMP sensor Epac as a determinant of ATP-sensitive potassium channel activity in human pancreatic beta cells and rat INS-1 cells. J. Physiol. 2006, 573, 595-609. [CrossRef] [PubMed]

85. Ozaki, N.; Shibasaki, T.; Kashima, Y.; Miki, T.; Takahashi, K.; Ueno, H.; Sunaga, Y.; Yano, H.; Matsuura, Y.; Iwanaga, T.; et al. cAMP-GEFII is a direct target of cAMP in regulated exocytosis. Nat. Cell Biol. 2000, 2, 805-811. [CrossRef]

86. Shibasaki, T.; Sunaga, Y.; Fujimoto, K.; Kashima, Y.; Seino, S. Interaction of ATP Sensor, cAMP Sensor, Ca ${ }^{2+}$ Sensor, and Voltage-dependent $\mathrm{Ca}^{2+}$ Channel in Insulin Granule Exocytosis. J. Biol. Chem. 2004, 279, 7956-7961. [CrossRef]

87. Shibasaki, T.; Sunaga, Y.; Seino, S. Integration of ATP, cAMP, and $\mathrm{Ca}^{2+}$ signals in insulin granule exocytosis. Diabetes 2004, 53, S59-S62. [CrossRef]

88. Braun, M.; Ramracheya, R.; Bengtsson, M.; Zhang, Q.; Karanauskaite, J.; Partridge, C.; Johnson, P.R.; Rorsman, P. Voltage-gated ion channels in human pancreatic beta-cells: Electrophysiological characterization and role in insulin secretion. Diabetes 2008, 57, 1618-1628. [CrossRef]

89. Jacobson, D.A.; Shyng, S.-L. Ion Channels of the Islets in Type 2 Diabetes. J. Mol. Biol. 2020, 432, 1326-1346. [CrossRef]

90. MacDonald, P.; Wheeler, M. Voltage-dependent $\mathrm{K}^{+}$channels in pancreatic beta cells: Role, regulation and potential as therapeutic targets. Diabetologia 2003, 46, 1046-1062. [CrossRef]

91. Yan, L.; Figueroa, D.J.; Austin, C.P.; Liu, Y.; Bugianesi, R.M.; Slaughter, R.S.; Kaczorowski, G.J.; Kohler, M.G. Expression of voltage-gated potassium channels in human and rhesus pancreatic islets. Diabetes 2004, 53, 597-607. [CrossRef]

92. Segerstolpe, A.; Palasantza, A.; Eliasson, P.; Andersson, E.M.; Andreasson, A.C.; Sun, X.; Picelli, S.; Sabirsh, A.; Clausen, M.; Bjursell, M.K.; et al. Single-Cell Transcriptome Profiling of Human Pancreatic Islets in Health and Type 2 Diabetes. Cell Metab. 2016, 24, 593-607. [CrossRef]

93. Li, X.N.; Herrington, J.; Petrov, A.; Ge, L.; Eiermann, G.; Xiong, Y.; Jensen, M.V.; Hohmeier, H.E.; Newgard, C.B.; Garcia, M.L.; et al. The role of voltage-gated potassium channels Kv2.1 and Kv2.2 in the regulation of insulin and somatostatin release from pancreatic islets. J. Pharmacol. Exp. Ther. 2013, 344, 407-416. [CrossRef] 
94. Liu, Y.; Zhong, X.; Ding, Y.; Ren, L.; Bai, T.; Liu, M.; Liu, Z.; Guo, Y.; Guo, Q.; Zhang, Y.; et al. Inhibition of voltage-dependent potassium channels mediates cAMP-potentiated insulin secretion in rat pancreatic beta cells. Islets 2017, 9, 11-18. [CrossRef]

95. Yoshida, M.; Dezaki, K.; Yamato, S.; Aoki, A.; Sugawara, H.; Toyoshima, H.; Ishikawa, S.E.; Kawakami, M.; Nakata, M.; Yada, T.; et al. Regulation of voltage-gated K+ channels by glucose metabolism in pancreatic beta-cells. FEBS Lett. 2009, 583, 2225-2230. [CrossRef]

96. Lee, C.H.; Chu, C.S.; Tsai, H.J.; Ke, L.Y.; Lee, H.C.; Yeh, J.L.; Chen, C.H.; Wu, B.N. Xanthine-derived KMUP-1 reverses glucotoxicityactivated $\mathrm{Kv}$ channels through the cAMP/PKA signaling pathway in rat pancreatic beta cells. Chem. Biol. Interact. 2018, 279, 171-176. [CrossRef] [PubMed]

97. Kim, S.J.; Choi, W.S.; Han, J.S.; Warnock, G.; Fedida, D.; McIntosh, C.H. A novel mechanism for the suppression of a voltage-gated potassium channel by glucose-dependent insulinotropic polypeptide: Protein kinase A-dependent endocytosis. J. Biol. Chem. 2005, 280, 28692-28700. [CrossRef]

98. Dai, X.Q.; Manning Fox, J.E.; Chikvashvili, D.; Casimir, M.; Plummer, G.; Hajmrle, C.; Spigelman, A.F.; Kin, T.; Singer-Lahat, D.; Kang, Y.; et al. The voltage-dependent potassium channel subunit Kv2.1 regulates insulin secretion from rodent and human islets independently of its electrical function. Diabetologia 2012, 55, 1709-1720. [CrossRef]

99. MacDonald, P.E.; Wang, G.; Tsuk, S.; Dodo, C.; Kang, Y.; Tang, L.; Wheeler, M.B.; Cattral, M.S.; Lakey, J.R.; Salapatek, A.M.; et al. Synaptosome-associated protein of 25 kilodaltons modulates $\mathrm{Kv} 2.1$ voltage-dependent $\mathrm{K}(+)$ channels in neuroendocrine islet beta-cells through an interaction with the channel $\mathrm{N}$ terminus. Mol. Endocrinol. 2002, 16, 2452-2461. [CrossRef]

100. Michaelevski, I.; Chikvashvili, D.; Tsuk, S.; Singer-Lahat, D.; Kang, Y.; Linial, M.; Gaisano, H.Y.; Fili, O.; Lotan, I. Direct interaction of target SNAREs with the Kv2.1 channel. Modal regulation of channel activation and inactivation gating. J. Biol. Chem. 2003, 278, 34320-34330. [CrossRef]

101. Islam, M.S. Molecular Regulations and Functions of the Transient Receptor Potential Channels of the Islets of Langerhans and Insulinoma Cells. Cells 2020, 9, 685. [CrossRef]

102. Lange, I.; Yamamoto, S.; Partida-Sanchez, S.; Mori, Y.; Fleig, A.; Penner, R. TRPM2 functions as a lysosomal Ca ${ }^{2+}$-release channel in beta cells. Sci. Signal 2009, 2, ra23. [CrossRef] [PubMed]

103. Uchida, K.; Dezaki, K.; Damdindorj, B.; Inada, H.; Shiuchi, T.; Mori, Y.; Yada, T.; Minokoshi, Y.; Tominaga, M. Lack of TRPM2 impaired insulin secretion and glucose metabolisms in mice. Diabetes 2011, 60, 119-126. [CrossRef] [PubMed]

104. Togashi, K.; Hara, Y.; Tominaga, T.; Higashi, T.; Konishi, Y.; Mori, Y.; Tominaga, M. TRPM2 activation by cyclic ADP-ribose at body temperature is involved in insulin secretion. EMBO J. 2006, 25, 1804-1815. [CrossRef] [PubMed]

105. Huang, Y.; Roth, B.; Lu, W.; Du, J. Ligand recognition and gating mechanism through three ligand-binding sites of human TRPM2 channel. Elife 2019, 8. [CrossRef]

106. Du, J.; Xie, J.; Yue, L. Intracellular calcium activates TRPM2 and its alternative spliced isoforms. Proc. Natl. Acad. Sci. USA 2009, 106, 7239-7244. [CrossRef]

107. Pang, B.; Kim, S.; Li, D.; Ma, Z.; Sun, B.; Zhang, X.; Wu, Z.; Chen, L. Glucagon-like peptide-1 potentiates glucose-stimulated insulin secretion via the transient receptor potential melastatin 2 channel. Exp. Med. 2017, 14, 5219-5227. [CrossRef]

108. Yosida, M.; Dezaki, K.; Uchida, K.; Kodera, S.; Lam, N.V.; Ito, K.; Rita, R.S.; Yamada, H.; Shimomura, K.; Ishikawa, S.E.; et al. Involvement of cAMP/EPAC/TRPM2 activation in glucose- and incretin-induced insulin secretion. Diabetes 2014, 63, 3394-3403. [CrossRef]

109. Kim, B.J.; Park, K.H.; Yim, C.Y.; Takasawa, S.; Okamoto, H.; Im, M.J.; Kim, U.H. Generation of nicotinic acid adenine dinucleotide phosphate and cyclic ADP-ribose by glucagon-like peptide- 1 evokes $\mathrm{Ca}^{2+}$ signal that is essential for insulin secretion in mouse pancreatic islets. Diabetes 2008, 57, 868-878. [CrossRef]

110. Ito, K.; Dezaki, K.; Yoshida, M.; Yamada, H.; Miura, R.; Rita, R.S.; Ookawara, S.; Tabei, K.; Kawakami, M.; Hara, K.; et al Endogenous $\alpha 2 \mathrm{~A}$-Adrenoceptor-Operated Sympathoadrenergic Tones Attenuate Insulin Secretion via cAMP/TRPM2 Signaling. Diabetes 2017, 66, 699. [CrossRef]

111. Kurashina, T.; Dezaki, K.; Yoshida, M.; Sukma Rita, R.; Ito, K.; Taguchi, M.; Miura, R.; Tominaga, M.; Ishibashi, S.; Kakei, M.; et al. The beta-cell GHSR and downstream cAMP/TRPM2 signaling account for insulinostatic and glycemic effects of ghrelin. Sci. Rep. 2015, 5, 14041. [CrossRef]

112. Du, J.; Xie, J.; Yue, L. Modulation of TRPM2 by acidic $\mathrm{pH}$ and the underlying mechanisms for pH sensitivity. J. Gen. Physiol. 2009, 134, 471-488. [CrossRef]

113. Holz, G.G.; Leech, C.A.; Habener, J.F. Activation of a cAMP-regulated Ca-Signaling Pathway in Pancreatic -Cells by the Insulinotropic Hormone Glucagon-like Peptide-1. J. Biol. Chem. 1995, 270, 17749-17757. [CrossRef]

114. Yada, T.; Itoh, K.; Nakata, M. Glucagon-like peptide-1-(7-36)amide and a rise in cyclic adenosine $3^{\prime}, 5^{\prime}$-monophosphate increase cytosolic free $\mathrm{Ca}^{2+}$ in rat pancreatic beta-cells by enhancing $\mathrm{Ca}^{2+}$ channel activity. Endocrinology 1993, 133, 1685-1692. [CrossRef]

115. Mourad, N.I.; Nenquin, M.; Henquin, J.C. cAMP-mediated and metabolic amplification of insulin secretion are distinct pathways sharing independence of beta-cell microfilaments. Endocrinology 2012, 153, 4644-4654. [CrossRef]

116. Kang, G.; Joseph, J.W.; Chepurny, O.G.; Monaco, M.; Wheeler, M.B.; Bos, J.L.; Schwede, F.; Genieser, H.-G.; Holz, G.G. Epacselective Analog 8-pCPT-2'-O-Me-cAMP as a Stimulus for $\mathrm{Ca}^{2+}$-induced $\mathrm{Ca}^{2+}$ Release and Exocytosis in Pancreatic $\beta$-Cells. J. Biol. Chem. 2003, 278, 8279-8285. [CrossRef]

117. Yada, T.; Hamakawa, N.; Yaekura, K. Two distinct modes of $\mathrm{Ca}^{2+}$ signalling by ACh in rat pancreatic beta-cells: Concentration, glucose dependence and $\mathrm{Ca}^{2+}$ origin. J. Physiol. 1995, 488, 13-24. [CrossRef] 
118. Weir, G.C.; Mojsov, S.; Hendrick, G.K.; Habener, J.F. Glucagonlike peptide I (7-37) actions on endocrine pancreas. Diabetes 1989, 38, 338-342. [CrossRef]

119. Lu, M.; Wheeler, M.B.; Leng, X.H.; Boyd, A.E., III. The role of the free cytosolic calcium level in beta-cell signal transduction by gastric inhibitory polypeptide and glucagon-like peptide I(7-37). Endocrinology 1993, 132, 94-100. [CrossRef]

120. Gromada, J.; Bokvist, K.; Ding, W.G.; Holst, J.J.; Nielsen, J.H.; Rorsman, P. Glucagon-like peptide 1 (7-36) amide stimulates exocytosis in human pancreatic beta-cells by both proximal and distal regulatory steps in stimulus-secretion coupling. Diabetes 1998, 47, 57-65. [CrossRef]

121. Holz, G.G.; Leech, C.A.; Heller, R.S.; Castonguay, M.; Habener, J.F. cAMP-dependent mobilization of intracellular Ca ${ }^{2+}$ stores by activation of ryanodine receptors in pancreatic beta-cells: $\mathrm{A} \mathrm{Ca}^{2+}$ signaling system stimulated by the insulinotropic hormone glucagon-like peptide-1-(7-37). J. Biol. Chem. 1999, 274, 14147-14156. [CrossRef]

122. Chepurny, O.G.; Kelley, G.G.; Dzhura, I.; Leech, C.A.; Roe, M.W.; Dzhura, E.; Li, X.; Schwede, F.; Genieser, H.G.; Holz, G.G. PKA-dependent potentiation of glucose-stimulated insulin secretion by Epac activator 8-pCPT-2'-O-Me-cAMP-AM in human islets of Langerhans. Am. J. Physiol. Endocrinol. Metab. 2010, 298, E622-E633. [CrossRef] [PubMed]

123. MacDonald, P.E.; El-Kholy, W.; Riedel, M.J.; Salapatek, A.M.; Light, P.E.; Wheeler, M.B. The multiple actions of GLP-1 on the process of glucose-stimulated insulin secretion. Diabetes 2002, 51, S434-S442. [CrossRef] [PubMed]

124. Salapatek, A.M.; MacDonald, P.E.; Gaisano, H.Y.; Wheeler, M.B. Mutations to the third cytoplasmic domain of the glucagon-like peptide 1 (GLP-1) receptor can functionally uncouple GLP-1-stimulated insulin secretion in HIT-T15 cells. Mol. Endocrinol. 1999, 13, 1305-1317. [CrossRef] [PubMed]

125. Jacobo, S.M.; Guerra, M.L.; Hockerman, G.H. Cav1.2 and Cav1.3 are differentially coupled to glucagon-like peptide-1 potentiation of glucose-stimulated insulin secretion in the pancreatic beta-cell line INS-1. J. Pharmacol. Exp. Ther. 2009, 331, 724-732. [CrossRef]

126. Liu, G.; Jacobo, S.M.; Hilliard, N.; Hockerman, G.H. Differential modulation of Cav1.2 and Cav1.3-mediated glucose-stimulated insulin secretion by cAMP in INS-1 cells: Distinct roles for exchange protein directly activated by cAMP 2 (Epac2) and protein kinase A. J. Pharmacol. Exp. Ther. 2006, 318, 152-160. [CrossRef]

127. Ammala, C.; Ashcroft, F.M.; Rorsman, P. Calcium-independent potentiation of insulin release by cyclic AMP in single [beta]-cells. Nature 1993, 363, 356-358. [CrossRef]

128. Kanno, T.; Suga, S.; Wu, J.; Kimura, M.; Wakui, M. Intracellular cAMP potentiates voltage-dependent activation of L-type Ca ${ }^{2+}$ channels in rat islet beta-cells. Pflug. Arch. Eur. J. Physiol. 1998, 435, 578-580. [CrossRef]

129. Kang, G.; Chepurny, O.G.; Rindler, M.J.; Collis, L.; Chepurny, Z.; Li, W.-H.; Harbeck, M.; Roe, M.W.; Holz, G.G. A cAMP and $\mathrm{Ca}^{2+}$ coincidence detector in support of $\mathrm{Ca}^{2+}$-induced $\mathrm{Ca}^{2+}$ release in mouse pancreatic $\beta$ cells. J. Physiol. 2005, 566, 173-188. [CrossRef]

130. Islam, M.S. Stimulus-Secretion Coupling in Beta-Cells: From Basic to Bedside. In Calcium Signaling; Islam, M.S., Ed.; Springer International Publishing: Cham, Switzerland, 2020; pp. 943-963.

131. Zhang, Q.; Bengtsson, M.; Partridge, C.; Salehi, A.; Braun, M.; Cox, R.; Eliasson, L.; Johnson, P.R.; Renstrom, E.; Schneider, T.; et al. R-type Ca(2+)-channel-evoked CICR regulates glucose-induced somatostatin secretion. Nat. Cell Biol. 2007, 9, 453-460. [CrossRef]

132. Postić, S.; Sarikas, S.; Pfabe, J.; Pohorec, V.; Bombek, L.K.; Sluga, N.; Klemen, M.S.; Dolenšek, J.; Korošak, D.; Stožer, A.; et al. Intracellular $\mathrm{Ca}^{2+}$ channels initiate physiological glucose signaling in beta cells examined in situ. bioRxiv 2021. [CrossRef]

133. Dzhura, I.; Chepurny, O.G.; Kelley, G.G.; Leech, C.A.; Roe, M.W.; Dzhura, E.; Afshari, P.; Malik, S.; Rindler, M.J.; Xu, X.; et al Epac2-dependent mobilization of intracellular $\mathrm{Ca}^{2+}$ by glucagon-like peptide-1 receptor agonist exendin-4 is disrupted in $\beta$-cells of phospholipase C- $\varepsilon$ knockout mice. J. Physiol. 2010, 588, 4871-4889. [CrossRef]

134. Islam, M.S. CICR takes centre stage in \{beta\}-cells: A cute cascade connects cAMP to CICR. J. Physiol. 2010, 588, 4853. [CrossRef]

135. Leech, C.A.; Chepurny, O.G.; Holz, G.G. Epac2-dependent rap1 activation and the control of islet insulin secretion by glucagon-like peptide-1. Vitam. Horm. 2010, 84, 279-302. [CrossRef]

136. Bode, H.-P.; Moormann, B.; Dabew, R.; Göke, B. Glucagon-Like Peptide 1 Elevates Cytosolic Calcium in Pancreatic $\beta$-Cells Independently of Protein Kinase A. Endocrinology 1999, 140, 3919-3927. [CrossRef]

137. Sasaki, S.; Nakagaki, I.; Kondo, H.; Hori, S. Involvement of the ryanodine-sensitive $\mathrm{Ca}^{2+}$ store in GLP-1-induced Ca ${ }^{2+}$ oscillations in insulin-secreting HIT cells. Pflug. Arch. Eur. J. Physiol. 2002, 445, 342-351. [CrossRef]

138. Dyachok, O.; Gylfe, E. $\mathrm{Ca}^{2+}$-induced $\mathrm{Ca}^{2+}$ Release via Inositol 1,4,5-trisphosphate Receptors Is Amplified by Protein Kinase A and Triggers Exocytosis in Pancreatic $\beta$-Cells. J. Biol. Chem. 2004, 279, 45455-45461. [CrossRef]

139. Leech, C.A.; Dzhura, I.; Chepurny, O.G.; Kang, G.; Schwede, F.; Genieser, H.G.; Holz, G.G. Molecular physiology of glucagon-like peptide-1 insulin secretagogue action in pancreatic beta cells. Prog. Biophys. Mol. Biol. 2011, 107, 236-247. [CrossRef]

140. Nordenskjöld, F.; Andersson, B.; Islam, M.S. Expression of the Inositol 1,4,5-Trisphosphate Receptor and the Ryanodine Receptor $\mathrm{Ca}^{2+}$-Release Channels in the Beta-Cells and Alpha-Cells of the Human Islets of Langerhans. In Calcium Signaling; Islam, M.S., Ed.; Springer International Publishing: Cham, Switzerland, 2020; pp. 271-279.

141. Dzhura, I.; Chepurny, O.G.; Leech, C.A.; Roe, M.W.; Dzhura, E.; Xu, X.; Lu, Y.; Schwede, F.; Genieser, H.-G.; Smrcka, A.V.; et al. Phospholipase $\mathrm{C}-\varepsilon$ links Epac2 activation to the potentiation of glucose-stimulated insulin secretion from mouse islets of Langerhans. Islets 2011, 3, 121-128. [CrossRef]

142. Kang, G.; Chepurny, O.G.; Holz, G.G. cAMP-regulated guanine nucleotide exchange factor II (Epac2) mediates Ca ${ }^{2+}$-induced $\mathrm{Ca}^{2+}$ release in INS-1 pancreatic beta-cells. J. Physiol. 2001, 536, 375-385. [CrossRef] 
143. Gromada, J.; Anker, C.; Bokvist, K.; Knudsen, L.B.; Wahl, P. Glucagon-like peptide-1 receptor expression in Xenopus oocytes stimulates inositol trisphosphate-dependent intracellular $\mathrm{Ca}^{2+}$ mobilization. FEBS Lett. 1998, 425, 277-280. [CrossRef]

144. Liu, Y.J.; Tengholm, A.; Grapengiesser, E.; Hellman, B.; Gylfe, E. Origin of slow and fast oscillations of $\mathrm{Ca}^{2+}$ in mouse pancreatic islets. J. Physiol. 1998, 508, 471-481. [CrossRef] [PubMed]

145. Baltrusch, S.; Lenzen, S. Regulation of $\left[\mathrm{Ca}^{2+}\right]$ i oscillations in mouse pancreatic islets by adrenergic agonists. Biochem Biophys Res Commun 2007, 363, 1038-1043. [CrossRef] [PubMed]

146. Cane, M.C.; Parrington, J.; Rorsman, P.; Galione, A.; Rutter, G.A. The two pore channel TPC2 is dispensable in pancreatic beta-cells for normal $\mathrm{Ca}(2)(+)$ dynamics and insulin secretion. Cell Calcium 2016, 59, 32-40. [CrossRef] [PubMed]

147. Šterk, M.; Križančić Bombek, L.; Skelin Klemen, M.; Slak Rupnik, M.; Marhl, M.; Stožer, A.; Gosak, M. NMDA receptor inhibition increases, synchronizes, and stabilizes the collective pancreatic beta cell activity: Insights through multilayer network analysis. PLoS Comput. Biol. 2021. [CrossRef] [PubMed]

148. Tengholm, A. Cyclic AMP dynamics in the pancreatic beta-cell. Ups. J. Med. Sci. 2012, 117, 355-369. [CrossRef]

149. Tian, G.; Sandler, S.; Gylfe, E.; Tengholm, A. Glucose- and hormone-induced cAMP oscillations in $\alpha$ - and $\beta$-cells within intact pancreatic islets. Diabetes 2011, 60, 1535-1543. [CrossRef]

150. Tengholm, A.; Gylfe, E. Oscillatory control of insulin secretion. Mol. Cell. Endocrinol. 2009, 297, 58-72. [CrossRef]

151. Flamez, D.; Gilon, P.; Moens, K.; Van Breusegem, A.; Delmeire, D.; Scrocchi, L.A.; Henquin, J.C.; Drucker, D.J.; Schuit, F. Altered cAMP and $\mathrm{Ca}^{2+}$ signaling in mouse pancreatic islets with glucagon-like peptide-1 receptor null phenotype. Diabetes 1999, 48 , 1979-1986. [CrossRef]

152. Bruton, J.; Cheng, A.J.; Westerblad, H. Measuring Ca ${ }^{2+}$ in Living Cells. In Calcium Signaling; Islam, M.S., Ed.; Springer International Publishing: Cham, Switzerland, 2020; pp. 7-26.

153. Gillis, K.D.; Misler, S. Enhancers of cytosolic cAMP augment depolarization-induced exocytosis from pancreatic B-cells: Evidence for effects distal to $\mathrm{Ca}^{2+}$ entry. Pflug. Arch. Eur. J. Physiol. 1993, 424, 195-197. [CrossRef]

154. Trogden, K.P.; Zhu, X.; Lee, J.S.; Wright, C.V.E.; Gu, G.; Kaverina, I. Regulation of Glucose-Dependent Golgi-Derived Microtubules by cAMP/EPAC2 Promotes Secretory Vesicle Biogenesis in Pancreatic beta Cells. Curr. Biol. CB 2019, 29, 2339-2350.e2335. [CrossRef]

155. Ying, Y.; Li, L.; Cao, W.; Yan, D.; Zeng, Q.; Kong, X.; Lu, L.; Yan, M.; Xu, X.; Qu, J.; et al. The microtubule associated protein syntabulin is required for glucose-stimulated and cAMP-potentiated insulin secretion. FEBS Lett. 2012, 586, 3674-3680. [CrossRef]

156. Henquin, J.C.; Nenquin, M. Activators of PKA and Epac distinctly influence insulin secretion and cytosolic Ca ${ }^{2+}$ in female mouse islets stimulated by glucose and tolbutamide. Endocrinology 2014, 155, 3274-3287. [CrossRef]

157. Alenkvist, I.; Gandasi, N.R.; Barg, S.; Tengholm, A. Recruitment of Epac2A to Insulin Granule Docking Sites Regulates Priming for Exocytosis. Diabetes 2017, 66, 2610-2622. [CrossRef]

158. Yasuda, T.; Shibasaki, T.; Minami, K.; Takahashi, H.; Mizoguchi, A.; Uriu, Y.; Numata, T.; Mori, Y.; Miyazaki, J.-i.; Miki, T.; et al. Rim $2 \alpha$ Determines Docking and Priming States in Insulin Granule Exocytosis. Cell Metab. 2010, 12, 117-129. [CrossRef]

159. Eliasson, L.; Ma, X.; Renstrom, E.; Barg, S.; Berggren, P.-O.; Galvanovskis, J.; Gromada, J.; Jing, X.; Lundquist, I.; Salehi, A.; et al. SUR1 Regulates PKA-independent cAMP-induced Granule Priming in Mouse Pancreatic B-cells. J. Gen. Physiol. 2003, 121, 181-197. [CrossRef]

160. Renström, E.; Eliasson, L.; Rorsman, P. Protein kinase A-dependent and -independent stimulation of exocytosis by cAMP in mouse pancreatic B-cells. J. Physiol. 1997, 502, 105-118. [CrossRef]

161. Vikman, J.; Svensson, H.; Huang, Y.C.; Kang, Y.; Andersson, S.A.; Gaisano, H.Y.; Eliasson, L. Truncation of SNAP-25 reduces the stimulatory action of cAMP on rapid exocytosis in insulin-secreting cells. Am. J. Physiol. Endocrinol. Metab. 2009, 297, E452-E461. [CrossRef]

162. Leung, Y.M.; Kwan, E.P.; Ng, B.; Kang, Y.; Gaisano, H.Y. SNAREing voltage-gated K+ and ATP-sensitive K+ channels: Tuning beta-cell excitability with syntaxin-1A and other exocytotic proteins. Endocr. Rev. 2007, 28, 653-663. [CrossRef]

163. Skelin, M.; Rupnik, M. cAMP increases the sensitivity of exocytosis to $\mathrm{Ca}^{2+}$ primarily through protein kinase A in mouse pancreatic beta cells. Cell Calcium 2011, 49, 89-99. [CrossRef]

164. Wan, Q.F.; Dong, Y.; Yang, H.; Lou, X.; Ding, J.; Xu, T. Protein kinase activation increases insulin secretion by sensitizing the secretory machinery to $\mathrm{Ca}^{2+}$. J. Gen. Physiol. 2004, 124, 653-662. [CrossRef]

165. Dolensek, J.; Skelin, M.; Rupnik, M.S. Calcium Dependencies of Regulated Exocytosis in Different Endocrine Cells. Physiol. Res. 2011, 60, S29-S38. [CrossRef] [PubMed]

166. Dolensek, J.; Rupnik, M.S.; Stozer, A. Structural similarities and differences between the human and the mouse pancreas. Islets 2015, 7, e1024405. [CrossRef] [PubMed]

167. Briant, L.J.B.; Reinbothe, T.M.; Spiliotis, I.; Miranda, C.; Rodriguez, B.; Rorsman, P. delta-cells and beta-cells are electrically coupled and regulate alpha-cell activity via somatostatin. J. Physiol. 2018, 596, 197-215. [CrossRef] [PubMed]

168. Gao, R.; Yang, T.; Zhang, Q. delta-Cells: The Neighborhood Watch in the Islet Community. Biology 2021, 10, 74. [CrossRef]

169. Benninger, R.K.; Hutchens, T.; Head, W.S.; McCaughey, M.J.; Zhang, M.; Le Marchand, S.J.; Satin, L.S.; Piston, D.W. Intrinsic islet heterogeneity and gap junction coupling determine spatiotemporal $\mathrm{Ca}(2)(+)$ wave dynamics. Biophys. J. 2014, 107, $2723-2733$. [CrossRef]

170. Benninger, R.K.P.; Hodson, D.J. New Understanding of beta-Cell Heterogeneity and In Situ Islet Function. Diabetes 2018, 67, 537-547. [CrossRef] 
171. Gosak, M.; Stozer, A.; Markovic, R.; Dolensek, J.; Marhl, M.; Rupnik, M.S.; Perc, M. The relationship between node degree and dissipation rate in networks of diffusively coupled oscillators and its significance for pancreatic beta cells. Chaos 2015, 25,07311 . [CrossRef]

172. Zmazek, J.; Klemen, M.S.; Markovič, R.; Dolenšek, J.; Marhl, M.; Stožer, A.; Gosak, M. Assessing Different Temporal Scales of Calcium Dynamics in Networks of Beta Cell Populations. Front. Physiol. 2021, 12, 612233. [CrossRef]

173. Šterk, M.; Dolenšek, J.; Bombek, L.K.; Markovič, R.; Zakelšek, D.; Perc, M.; Pohorec, V.; Stožer, A.; Gosak, M. Assessing the origin and velocity of $\mathrm{Ca}^{2+}$ waves in three-dimensional tissue: Insights from a mathematical model and confocal imaging in mouse pancreas tissue slices. Commun. Nonlinear Sci. Numer. Simul. 2021, 93, 105495. [CrossRef]

174. Stožer, A.; Gosak, M.; Dolenšek, J.; Perc, M.; Marhl, M.; Rupnik, M.S.; Korošak, D. Functional Connectivity in Islets of Langerhans from Mouse Pancreas Tissue Slices. PLoS Comput. Biol. 2013, 9, e1002923. [CrossRef]

175. Stožer, A.; Gosak, M.; Korošak, D.; Yakubo, K.; Dolenšek, J.; Marhl, M.; Rupnik, M.S. Correlations between beta-cells' calcium dynamics reveal differences in functional connectivity patterns in islets of Langerhans from pancreas tissue slices under low and high levels of glucose. AIP Conf. Proc. 2012, 1468, 332-339.

176. Cappon, G.; Pedersen, M.G. Heterogeneity and nearest-neighbor coupling can explain small-worldness and wave properties in pancreatic islets. Chaos 2016, 26, 053103. [CrossRef]

177. Johnston, N.R.; Mitchell, R.K.; Haythorne, E.; Pessoa, M.P.; Semplici, F.; Ferrer, J.; Piemonti, L.; Marchetti, P.; Bugliani, M.; Bosco, D.; et al. Beta Cell Hubs Dictate Pancreatic Islet Responses to Glucose. Cell Metab. 2016, 24, 389-401. [CrossRef]

178. Gosak, M.; Markovic, R.; Dolensek, J.; Slak Rupnik, M.; Marhl, M.; Stozer, A.; Perc, M. Network science of biological systems at different scales: A review. Phys Life Rev. 2018, 24, 118-135. [CrossRef]

179. Charpantier, E.; Cancela, J.; Meda, P. Beta cells preferentially exchange cationic molecules via connexin 36 gap junction channels. Diabetologia 2007, 50, 2332-2341. [CrossRef]

180. Bukauskas, F.F. Neurons and beta-cells of the pancreas express connexin36, forming gap junction channels that exhibit strong cationic selectivity. J. Membr. Biol. 2012, 245, 243-253. [CrossRef]

181. Meda, P.; Amherdt, M.; Perrelet, A.; Orci, L. Metabolic coupling between cultured pancreatic b-cells. Exp. Cell Res. 1981, 133, 421-430. [CrossRef]

182. Meda, P.; Kohen, E.; Kohen, C.; Orci, L. Heterocellular coupling in cultures of endocrine pancreatic cells. C. R. Seances Acad. Sci. III 1981, 293, 607-610.

183. Pedersen, M.G.; Bertram, R.; Sherman, A. Intra- and inter-islet synchronization of metabolically driven insulin secretion. Biophys. J. 2005, 89, 107-119. [CrossRef]

184. Cigliola, V.; Chellakudam, V.; Arabieter, W.; Meda, P. Connexins and $\beta$-cell functions. Diabetes Res. Clin. Pract. 2013, 99, 250-259. [CrossRef]

185. Rao, V.P.; Rizzo, M.A. Diffusion of metabolites across gap junctions mediates metabolic coordination of $\beta$-islet cells. bioRxiv 2020. [CrossRef]

186. Carvalho, C.P.F.; Oliveira, R.B.; Britan, A.; Santos-Silva, J.C.; Boschero, A.C.; Meda, P.; Collares-Buzato, C.B. Impaired $\beta$-cell- $\beta$-cell coupling mediated by Cx36 gap junctions in prediabetic mice. Am. J. Physiol. Endocrinol. Metab. 2012, 303, E144-E151. [CrossRef]

187. Allagnat, F.; Martin, D.; Condorelli, D.F.; Waeber, G.; Haefliger, J.-A. Glucose represses connexin36 in insulin-secreting cells. J. Cell Sci. 2005, 118, 5335-5344. [CrossRef]

188. Irles, E.; Neco, P.; Lluesma, M.; Villar-Pazos, S.; Santos-Silva, J.C.; Vettorazzi, J.F.; Alonso-Magdalena, P.; Carneiro, E.M.; Boschero, A.C.; Nadal, A.; et al. Enhanced glucose-induced intracellular signaling promotes insulin hypersecretion: Pancreatic beta-cell functional adaptations in a model of genetic obesity and prediabetes. Mol. Cell Endocrinol. 2015, 404, 46-55. [CrossRef] [PubMed]

189. Farnsworth, N.L.; Walter, R.L.; Hemmati, A.; Westacott, M.J.; Benninger, R.K.P. Low Level Pro-inflammatory Cytokines Decrease Connexin36 Gap Junction Coupling in Mouse and Human Islets through Nitric Oxide-mediated Protein Kinase C $\delta$. J. Biol. Chem. 2016, 291, 3184-3196. [CrossRef]

190. Perez-Armendariz, E.M. Connexin 36, a key element in pancreatic beta cell function. Neuropharmacology 2013, 75, 557-566. [CrossRef] [PubMed]

191. Rutter, G.A.; Georgiadou, E.; Martinez-Sanchez, A.; Pullen, T.J. Metabolic and functional specialisations of the pancreatic beta cell: Gene disallowance, mitochondrial metabolism and intercellular connectivity. Diabetologia 2020, 63, 1990-1998. [CrossRef] [PubMed]

192. Corezola do Amaral, M.E.; Kravets, V.; Dwulet, J.M.; Farnsworth, N.L.; Piscopio, R.; Schleicher, W.E.; Miranda, J.G.; Benninger, R.K.P. Caloric restriction recovers impaired $\beta$-cell- $\beta$-cell gap junction coupling, calcium oscillation coordination, and insulin secretion in prediabetic mice. Am. J. Physiol. Endocrinol. Metab. 2020, 319, E709-E720. [CrossRef]

193. Pérez-Armendariz, M.; Roy, C.; Spray, D.C.; Bennett, M.V. Biophysical properties of gap junctions between freshly dispersed pairs of mouse pancreatic beta cells. Biophys. J. 1991, 59, 76-92. [CrossRef]

194. Allagnat, F.; Alonso, F.; Martin, D.; Abderrahmani, A.; Waeber, G.; Haefliger, J.A. ICER-1gamma overexpression drives palmitatemediated connexin36 down-regulation in insulin-secreting cells. J. Biol. Chem. 2008, 283, 5226-5234. [CrossRef]

195. Haefliger, J.-A.; Martin, D.; Favre, D.; Petremand, Y.; Mazzolai, L.; Abderrahmani, A.; Meda, P.; Waeber, G.; Allagnat, F. Reduction of Connexin36 Content by ICER-1 Contributes to Insulin-Secreting Cells Apoptosis Induced by Oxidized LDL Particles. PLoS ONE 2013, 8, e55198. [CrossRef] 
196. Kothmann, W.W.; Massey, S.C.; O’Brien, J. Dopamine-stimulated dephosphorylation of connexin 36 mediates AII amacrine cell uncoupling. J. Neurosci. Off. J. Soc. Neurosci. 2009, 29, 14903-14911. [CrossRef]

197. Calabrese, A.; Zhang, M.; Serre-Beinier, V.; Caton, D.; Mas, C.; Satin, L.S.; Meda, P. Connexin 36 Controls Synchronization of Ca ${ }^{2+}$ Oscillations and Insulin Secretion in MIN6 Cells. Diabetes 2003, 52, 417-424. [CrossRef]

198. Moreno, A.P.; Lau, A.F. Gap junction channel gating modulated through protein phosphorylation. Prog. Biophys. Mol. Biol. 2007, 94, 107-119. [CrossRef]

199. Skelin Klemen, M.; Dolenšek, J.; Križančić Bombek, L.; Pohorec, V.; Gosak, M.; Slak Rupnik, M.; Stožer, A. The Effect of cAMP and the Role of Epac2A During Activation, Activity, and Deactivation of Beta Cell Networks. Preprints 2021. [CrossRef]

200. Stožer, A.; Dolenšek, J.; Križančić Bombek, L.; Pohorec, V.; Slak Rupnik, M.; Klemen, M.S. Confocal Laser Scanning Microscopy of Calcium Dynamics in Acute Mouse Pancreatic Tissue Slices. JoVE 2021, e62293. [CrossRef]

201. Stozer, A.; Hojs, R.; Dolensek, J. Beta Cell Functional Adaptation and Dysfunction in Insulin Resistance and the Role of Chronic Kidney Disease. Nephron 2019, 143, 33-37. [CrossRef]

202. Kahn, S.E.; Cooper, M.E.; Del Prato, S. Pathophysiology and treatment of type 2 diabetes: Perspectives on the past, present, and future. Lancet 2014, 383, 1068-1083. [CrossRef]

203. Kargar, C.; Ktorza, A. Anatomical versus functional beta-cell mass in experimental diabetes. Diabetes Obes. Metab. 2008, 10, 43-53. [CrossRef]

204. Saisho, Y.; Butler, A.E.; Manesso, E.; Elashoff, D.; Rizza, R.A.; Butler, P.C. beta-cell mass and turnover in humans: Effects of obesity and aging. Diabetes Care 2013, 36, 111-117. [CrossRef]

205. Rahier, J.; Guiot, Y.; Goebbels, R.M.; Sempoux, C.; Henquin, J.C. Pancreatic $\beta$-cell mass in European subjects with type 2 diabetes. Diabetes Obes. Metab. 2008, 10, 32-42. [CrossRef]

206. Kou, K.; Saisho, Y.; Satoh, S.; Yamada, T.; Itoh, H. Change in beta-cell mass in Japanese nondiabetic obese individuals. J. Clin. Endocrinol. Metab. 2013, 98, 3724-3730. [CrossRef]

207. Karaca, M.; Magnan, C.; Kargar, C. Functional pancreatic beta-cell mass: Involvement in type 2 diabetes and therapeutic intervention. Diabetes Amp. Metab. 2009, 35, 77-84. [CrossRef]

208. Shen, C.-a.; Fagan, S.; Fischman, A.J.; Carter, E.E.; Chai, J.-K.; Lu, X.-M.; Yu, Y.-M.; Tompkins, R.G. Effects of glucagon-like peptide 1 on glycemia control and its metabolic consequence after severe thermal injury-studies in an animal model. Surgery 2011, 149, 635-644. [CrossRef]

209. Sah, S.P.; Singh, B.; Choudhary, S.; Kumar, A. Animal models of insulin resistance: A review. Pharmacol. Rep. 2016, 68, 1165-1177. [CrossRef]

210. Butler, A.E.; Janson, J.; Bonner-Weir, S.; Ritzel, R.; Rizza, R.A.; Butler, P.C. beta-cell deficit and increased beta-cell apoptosis in humans with type 2 diabetes. Diabetes 2003, 52, 102-110. [CrossRef]

211. Wang, Q.; Zhao, C.; Jin, L.; Zhang, H.; Miao, Q.; Liu, H.; Zhang, D. AWRK6, a Novel GLP-1 Receptor Agonist, Attenuates Diabetes by Stimulating Insulin Secretion. Int. J. Mol. Sci. 2018, 19, 3053. [CrossRef] [PubMed]

212. Hull, R.L.; Kodama, K.; Utzschneider, K.M.; Carr, D.B.; Prigeon, R.L.; Kahn, S.E. Dietary-fat-induced obesity in mice results in beta cell hyperplasia but not increased insulin release: Evidence for specificity of impaired beta cell adaptation. Diabetologia 2005, 48, 1350-1358. [CrossRef] [PubMed]

213. Grapengiesser, E.; Gylfe, E.; Hellman, B. Glucose-induced oscillations of cytoplasmic $\mathrm{Ca}^{2+}$ in the pancreatic $\beta$-cell. Biochem. Biophys. Res. Commun. 1988, 151, 1299-1304. [CrossRef]

214. Gylfe, E.; Grapengiesser, E.; Hellman, B. Propagation of cytoplasmic $\mathrm{Ca}^{2+}$ oscillations in clusters of pancreatic $\beta$-cells exposed to glucose. Cell Calcium 1991, 12, 229-240. [CrossRef]

215. Santos, R.M.; Rosario, L.M.; Nadal, A.; Garcia-Sancho, J.; Soria, B.; Valdeolmillos, M. Widespread synchronous Ca oscillations due to bursting electrical activity in single pancreatic islets. Pflüg. Arch. Eur. J. Physiol. 1991, 418, 417-422. [CrossRef]

216. Gopel, S.; Zhang, Q.; Eliasson, L.; Ma, X.S.; Galvanovskis, J.; Kanno, T.; Salehi, A.; Rorsman, P. Capacitance measurements of exocytosis in mouse pancreatic alpha-, beta- and delta-cells within intact islets of Langerhans. J. Physiol. 2004, 556, 711-726. [CrossRef]

217. Gonzalez, A.; Merino, B.; Marroqui, L.; Neco, P.; Alonso-Magdalena, P.; Caballero-Garrido, E.; Vieira, E.; Soriano, S.; Gomis, R.; Nadal, A.; et al. Insulin hypersecretion in islets from diet-induced hyperinsulinemic obese female mice is associated with several functional adaptations in individual beta-cells. Endocrinology 2013, 154, 3515-3524. [CrossRef]

218. Westacott, M.J.; Farnsworth, N.L.; St Clair, J.R.; Poffenberger, G.; Heintz, A.; Ludin, N.W.; Hart, N.J.; Powers, A.C.; Benninger, R.K.P. Age-Dependent Decline in the Coordinated $[\mathrm{Ca}(2+)]$ and Insulin Secretory Dynamics in Human Pancreatic Islets. Diabetes 2017, 66, 2436-2445. [CrossRef]

219. Holz, G.G.; Chepurny, O.G.; Leech, C.A. Epac2A makes a new impact in beta-cell biology. Diabetes 2013, 62, 2665-2666. [CrossRef]

220. Idevall-Hagren, O.; Jakobsson, I.; Xu, Y.; Tengholm, A. Spatial control of Epac2 activity by cAMP and Ca ${ }^{2+}$-mediated activation of Ras in pancreatic beta cells. Sci. Signal 2013, 6, ra29. [CrossRef]

221. Park, J.H.; Shim, H.M.; Na, A.Y.; Bae, J.H.; Im, S.S.; Song, D.K. Orexin A regulates plasma insulin and leptin levels in a time-dependent manner following a glucose load in mice. Diabetologia 2015, 58, 1542-1550. [CrossRef]

222. Shen, Y.; Zhao, Y.; Zheng, D.; Chang, X.; Ju, S.; Guo, L. Effects of orexin A on GLUT4 expression and lipid content via MAPK signaling in 3T3-L1 adipocytes. J. Steroid Biochem. Mol. Biol. 2013, 138, 376-383. [CrossRef] 
223. Arafat, A.M.; Kaczmarek, P.; Skrzypski, M.; Pruszynska-Oszmalek, E.; Kolodziejski, P.; Adamidou, A.; Ruhla, S.; Szczepankiewicz, D.; Sassek, M.; Billert, M.; et al. Glucagon regulates orexin A secretion in humans and rodents. Diabetologia 2014, 57, 2108-2116. [CrossRef]

224. Baranowska, B.; Wolinska-Witort, E.; Martynska, L.; Chmielowska, M.; Baranowska-Bik, A. Plasma orexin A, orexin B, leptin, neuropeptide Y (NPY) and insulin in obese women. Neuro Endocrinol. Lett. 2005, 26, 293-296.

225. Blanchet, E.; Van de Velde, S.; Matsumura, S.; Hao, E.; LeLay, J.; Kaestner, K.; Montminy, M. Feedback inhibition of CREB signaling promotes beta cell dysfunction in insulin resistance. Cell Rep. 2015, 10, 1149-1157. [CrossRef]

226. Takahashi, H.; Shibasaki, T.; Park, J.H.; Hidaka, S.; Takahashi, T.; Ono, A.; Song, D.K.; Seino, S. Role of Epac2A/Rap1 signaling in interplay between incretin and sulfonylurea in insulin secretion. Diabetes 2015, 64, 1262-1272. [CrossRef] 